\title{
Rubble Stone Masonry Buildings With Cement Mortar: Design Specifications in Seismic and Masonry Codes Worldwide
}

\author{
Martijn Schildkamp ${ }^{1 *}$, Stefano Silvestri ${ }^{2}$ and Yoshikazu Araki ${ }^{3}$ \\ ${ }^{1}$ Smart Shelter Research, Alphen aan den Rijn, Netherlands, ${ }^{2}$ Department of Civil, Chemical, Environmental and Materials \\ Engineering, University of Bologna, Bologna, Italy, ${ }^{3}$ Graduate School of Environmental Studies, Nagoya University, Nagoya, \\ Japan
}

OPEN ACCESS

Edited by: Ricardo Monteiro, University School of Advanced Studies IUSS, Italy

Reviewed by:

João M. C. Estêvão,

University of Algarve, Portugal

Michele Betti,

University of Florence, Italy

*Correspondence:

Martijn Schildkamp

info@smartshelterresearch.com

Specialty section:

This article was submitted to Earthquake Engineering,

a section of the journal

Frontiers in Built Environment

Received: 01 August 2020 Accepted: 22 September 2020

Published: 20 October 2020

Citation:

Schildkamp M, Silvestri S and Araki Y (2020) Rubble Stone Masonry Buildings With Cement Mortar: Design Specifications in Seismic and Masonry Codes Worldwide. Front. Built Environ. 6:590520. doi: 10.3389/fbuil.2020.590520
Nearly 325 seismic and masonry codes from all over the world have been analyzed, of countries where stone masonry was, or still is, abundantly practiced. This paper compares and summarizes design specifications and construction requirements, with a specific focus on "nominally reinforced rubble stone masonry (NRM) with cement mortar and wooden diaphragms in seismic areas." Currently, the technique is only allowed and described in some detail in the codes of Nepal, India, China, Tajikistan, Georgia, Iran and Croatia. It is concluded that the design specifications vary greatly without any consensus on the main sizes, dimensions or details. This raises questions about the completeness and correctness, as well as the reliability and actual value of the knowledge in this field. It is further observed that types of stone masonry and stone properties are seldom clearly described in the codes. It is also noted that several countries where stone masonry is still broadly practiced, are currently not allowing the technique (or have no codes in place), such as Afghanistan, Pakistan, Bhutan, Azerbaijan, Kyrgyzstan, Morocco, Tunisia, Turkey, Yemen and Albania. This, however, does not serve the current engineering practices and construction needs in these countries. To address all shortcomings, the paper recommends clear descriptions and terminology; the international adaption of NRM as a fourth masonry category; and the development of a stand-alone code specifically for this technique. Therefore, the authors propose a full assessment, validation, optimization and complementation of the existing knowledge, by means of the current state-of-the-art for calculating, testing and modeling. This envisions a structured research approach with focus on vernacular and traditional construction techniques, called "Non-Engineered 2.0," for which a research initiative is started under the name "SMARTnet," meaning "Seismic Methodologies for Applied Research and Testing of non-engineered techniques." The findings of this paper will serve as the starting point for the upcoming follow-up paper, which will complement the seismic demand with hand-made base shear calculations for countries that still allow the technique. The paper ends with an appeal to experts, academics and finalyear students worldwide, to exchange their knowledge and to support the project with their time and expertise.

Keywords: rubble stone masonry, cement mortar, design specifications, seismic codes, masonry codes 


\section{INTRODUCTION}

Between 2007 and 2012 the Dutch NGO Smart Shelter Foundation (SSF) built earthquake-resistant schools in rubble stone masonry in Nepal, and these buildings have survived the 2015 Gorkha earthquakes without any significant damage. The designs were developed by SSF following general rules of thumb, as found in several practical field manuals that address "non-engineered seismic design." The term "non-engineered" for buildings refers to "those which are spontaneously and informally constructed in various countries in the traditional manner, without any or little intervention by qualified architects and engineers in their design" (Arya, 2000).

However, in-depth technical verification or validated calculations for stone masonry buildings are not available in the literature nor national codes. The available empirical knowledge is based on just a few publications from the 1980s which have not been updated since, as concluded by Schildkamp and Araki (2019a). It was already noted in 1977 that "a review of the earthquake codes of various countries shows that much of the information is empirically based and not theoretically derived. In that respect, the recommendations must be subject to continuous review and change as more data become available" (Arya, 1977). Effectively this has not been undertaken to date, and therefore the authors of this paper have started a research group with the aim of upgrading the knowledge and improving the seismic resilience of rubble stone masonry, to be published in a series of papers that already includes a literature review of practical manuals, and a detailed cost analysis (Schildkamp and Araki, 2019a,b).

This is the third paper in that series. The objective is to analyze and compare current practices of rubble stone masonry buildings with the design specifications and construction requirements, as dictated by national seismic and masonry codes. The focus is on newly constructed houses and schools, for which the specific search criteria are described in the next chapter. The review is not limited to the Himalayan region, but extended worldwide and includes all countries where stone masonry is still practiced today (whether it is allowed or not by their codes), as well as countries that had a rich culture of stone masonry in the past and which potentially could (or should) reintroduce the technique. It compares the main design requirements, such as overall length, width and height dimensions of the buildings; minimum and/or maximum thickness and dimensions of walls elements and openings; and specifications of main horizontal and vertical reinforcements. A final table summarizes all design requirements as dictated by the national codes in which stone masonry is currently still allowed. Based on these specifications, two case study buildings will be developed and presented for further detailed seismic analysis and calculations in the follow-up papers (comparisons of base shear seismic demand, to be checked with seismic capacity verifications). This paper ends with some recommendations for improvement in clarity and wording, in the summary and conclusion. To our knowledge, such extensive and complete overview with regards to rubble stone masonry in seismic areas has not been presented before.

\section{SEARCH CRITERIA: MATERIAL AND BUILDING TYPOLOGIES}

The following specific type of stone masonry and building typologies are under consideration, based on the stone masonry projects as designed and built in Nepal by SSF, and explained in detail in the first paper in this series:

- Type of stone unit: The focus is on random rubble stone (Figure 1A), meaning stones that are uncut, unsquared, irregularly shaped and non-dimensioned. This contrasts with stones that are cut, squared and dimensioned into a regular-sized parallelepiped shape, which is known as "Ashlar" (Figure 1B). As the process of shaping is time-consuming and costly, Ashlar is not often used for rural and remote construction in developing countries. Rubble stones are placed in leveled courses to obtain a certain level of bonding and stability in the walls. Round (river) boulders are not recommended for stone masonry buildings in earthquake-prone areas.

- Type of mortar: The choice of mortar type has a huge impact on the strength characteristics of the masonry. Cement-sand mortar is preferred, as history has shown on many occasions that stone masonry with mud mortar does not perform well in earthquakes. For instance, after the 2015 Gorkha earthquake in Nepal it was estimated that roughly 980,000 schools and houses were damaged and destroyed throughout the country, of which over $80 \%$ took place in the rural areas, of which $95 \%$ consisted of low-strength masonry; the majority being stone with mud mortar (National Planning Commission, 2015).

- Type of masonry: Masonry is generally divided into 3 main types, being Unreinforced Masonry (URM), Confined Masonry (CM) and Reinforced Masonry (RM), as described by Silva et al. (2018). URM, as the name implies, has no reinforcements whatsoever. However, in seismic engineering this terminology is somewhat misleading since not one national code allows "pure" URM, due to bad behavior in past earthquakes; all require "URM with the addition of certain nominal reinforcements" such as continuous horizontal bands, or the inclusion of vertical elements at critical junctions. Therefore, to avoid any further confusion, the authors of this paper propose the introduction of a fourth type of masonry, as well as the international adoption of the term "Nominally Reinforced Masonry" (NRM) in conjunction with the existing types of URM, CM and RM. It is important to note that the buildings by SSF in Nepal have only incorporated horizontal bands in the walls, and that any vertical steel reinforcements are excluded. It is reasoned that a limited amount of steel will not provide sufficient ductility in the thick walls. Further, any vertical reinforcement will disrupt the masonry bonding in corners and T-junctions, possibly making these important connections weaker, rather than stronger. This is a key research objective we aim to validate in this series of papers. 

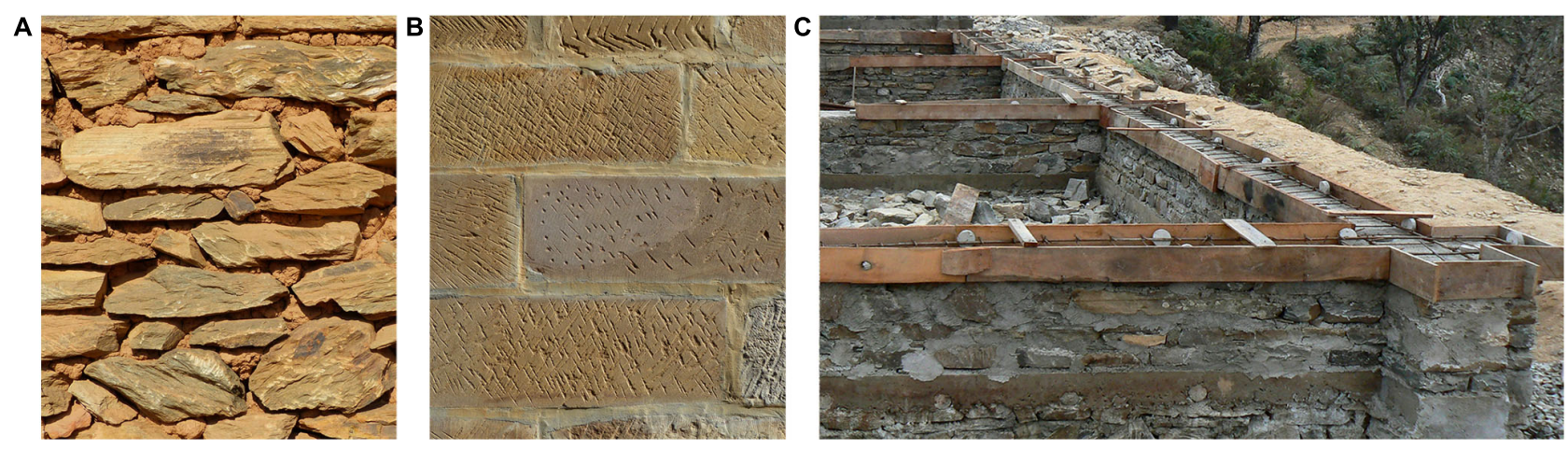

FIGURE 1 | (A) Unreinforced random rubble stone masonry with mud mortar. (B) Unreinforced Ashlar stone masonry with lime-sand mortar. (C) Nominally reinforced random rubble stone masonry with cement mortar and brought to courses (all by courtesy of Smart Shelter Foundation).

- Type of buildings: Single-family houses and small school buildings.

- Type of floors and roofs: Wooden floors and wood-trussed roofs, as opposed to concrete slabs.

To summarize all the above parameters in one sentence, this worldwide review is focusing on the specific characteristics of "low-rise buildings with cement-mortared rubble stone masonry walls, that are brought to courses and nominally reinforced with reinforced concrete bands, with wooden floors and a woodtrussed roof" (Figure 1C).

This section describes the historic background and analyzes the current possibilities and limitations of rubble stone masonry, following the criteria as described in this chapter. Nearly 325 seismic and masonry codes of countries worldwide have been analyzed, divided over 5 continents and in different time frames going back as far as the nineteenth century. The focus is on those countries where the technique is still being utilized, as well as on countries where it potentially could be used (again). Countries are grouped by region such as the Himalayas, Central Asia, the Caucasus, the Middle East, Northern Africa, and parts of East and South Europe. The review aims to trace when and where certain rules came into existence, how they have changed over time, and if there are similarities between codes and countries.

Several countries that possess a high seismic risk have been excluded from the review since these never had a past history nor have a present culture of stone masonry, such as Japan, Taiwan, Indonesia, the Philippines, United States, Canada and New Zealand. For the same reason, all South and Central American countries that have significant seismic hazard are excluded as well. Here the main construction practices for lowrise and low-cost housing consist of natural materials such as bamboo and earth (adobe, rammed earth, wattle-and-daub), or Confined Masonry with bricks or concrete blocks. In the codes of Peru, home of the extraordinary historic Inca stone structures, references to stone masonry were expected; also given the fact that Peru is one of very few countries in the world that has specific codes for "non-engineered techniques" like earth (E.080, 2017) and bamboo (E.100, 2012). But other than a few minor remarks about using stones in foundations and civic works, nothing for rubble stone masonry is described in any of the national codes of Argentina, Chile, Peru, Ecuador, Colombia, Venezuela, Panama, Costa Rica, Nicaragua, Honduras, El Salvador, Guatemala, Mexico, Dominican Republic, Haiti and Cuba. A plausible reason is summarized by one line in the seismic code of Costa Rica: "Historical constructions and monuments that have a cultural or historical value, many times are built with materials that are not commonly used today, such as adobe, bahareque and stone" (CSCR-2010, 2014).

It is important to note that all codes are read and analyzed in their original languages by at least one (and preferably two) native speaking experts from each country; all acknowledged at the end of the paper. Except for China, most Himalayan codes are primarily published in English, but this is not the case for almost all other countries. Furthermore, the codes are followed as literally as possible, aiming to avoid opinion and interpretation.

\section{Rubble Stone Masonry in the Himalayan Region}

The Alpine-Himalayan belt is one of the most earthquake-prone regions in the world, caused by movement of the Indian Plate toward the Eurasian Plate with a rate of approximately $35-50 \mathrm{~mm}$ between western to eastern plate boundaries (Jade et al., 2017). Rubble stone masonry remains to be a primary construction method in this region and the review of the Himalayas includes Nepal, India, Pakistan and China. Afghanistan is often regarded as part of Central Asia, but since they follow US-based rather than Russian-based codes, the country is included here. The kingdom of Bhutan, where stone masonry is still abundantly used, does not have a seismic or masonry code of its own and refers to the Indian codes (Thinley et al., 2017). Stone masonry is only discussed in its Bhutanese Architecture Guidelines (Royal Government of Bhutan, 2014), which focuses solely on aesthetic features of buildings such as building shape, roof form and window ornamentation, without any consideration for structural stability of the building. Bangladesh, although bordering the Northeastern Indian states where stone masonry is broadly practiced, does not have a culture of stone masonry and the technique is not mentioned in their building code (BNBC-2017, 


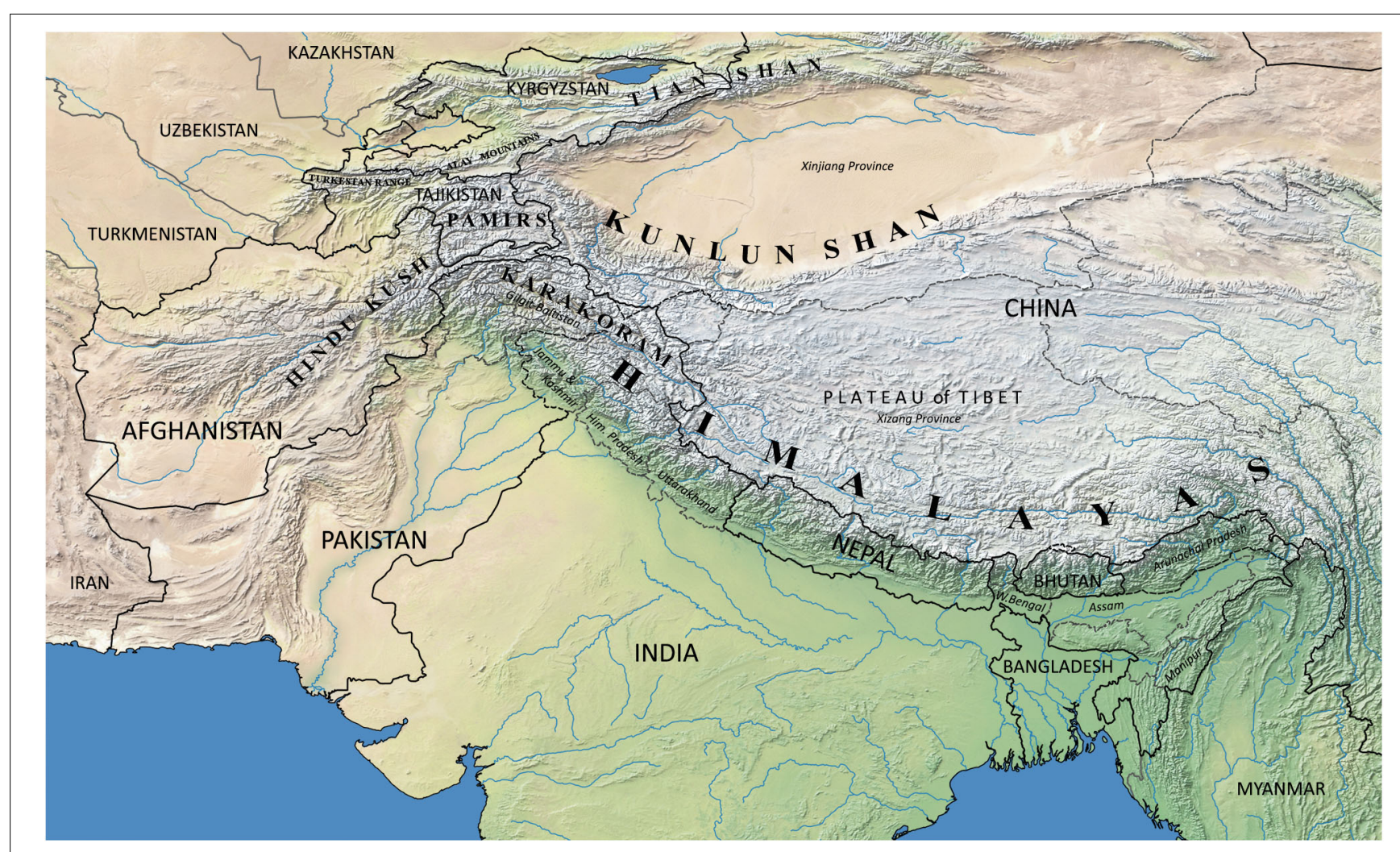

FIGURE 2 | Main mountain ranges of the South and Central Asian regions (original source: Natural Earth raster + vector map).

2017). The countries east of the Himalayas bordering China and extending further into Southeast Asia either have a low seismic risk, or rubble stone is not a common material for buildings, such as Myanmar, Laos, Thailand, and Vietnam. Figure 2 shows the main mountain ranges in the South and Central Asian regions.

\section{Nepal}

The first set of Nepal's National Building Codes (NBC) was published in 1994 after the 1988 Udayapur earthquake in Eastern Nepal. The first seismic code NBC 105:1994 (2007) divided the country in 3 seismic risk zones: A-widespread damage and collapse; $\mathrm{B}-$ moderate damage; and $\mathrm{C}-$ minor damage, but it did not address different techniques or materials. Regarding stone masonry, the codes of interest were NBC 202:1994 (2007) "Mandatory Rules of Thumb for Loadbearing Masonry" and NBC 203:1994 (2007) "Guidelines for Earthquake-Resistant Construction of Low-Strength Masonry," but the information was perceived as highly contradicting and confusing (Schildkamp and Araki, 2019a). The first revisions in 20 years, although completed just before the devastating Gorkha earthquakes in 2015, were made available to the public 4 years later; in June 2019. Here the techniques of stone masonry with cement mortar (NBC 202:2015, 2015) and mud mortar (NBC 203:2015, 2015) are more clearly divided. The objective of NBC 202 is "to introduce earthquake-resistant features to non-engineered buildings in order to achieve an appropriate level of earthquake resistance (...) it does not render masonry buildings able to totally withstand any earthquake without any appreciable damage, however, it is intended to limit the damage to a level which does not threaten human lives and which can be repaired quickly." The code covers rubble stone buildings in cement mortar with a maximum height of 2 stories plus attic (although not recommended on soft soil), a free wall span of $4.5 \mathrm{~m}$ and a maximum room area of $13.5 \mathrm{~m}^{2}$. It describes a maximum floorto-floor height of $3.0 \mathrm{~m}$, minimum wall thickness $0.35 \mathrm{~m}$, and minimum masonry width in corners, as well as for piers, of 600 $\mathrm{mm}$. It further recommends replacing heavy masonry gables with a light wooden alternative. Horizontal bands and reinforcements must be included at 6 levels (plinth, sill, lintel, top, and stitches at two levels), and vertical bars at all critical wall connections and jambs of openings. Mortar shall not be leaner than 1:6 cementsand ratio with a minimum compression strength of $3.0 \mathrm{~N} / \mathrm{mm}^{2}$ at 28 days, according to the (unrevised) code NBC 109:1994 (2007) "Masonry Unreinforced."

All these recommendations are meant for residential buildings, as NBC 202 specifies that its rules do not apply for important buildings such as schools. However, school designs that are made by qualified professionals may be approved by the local authorities, of which examples are published online by the Nepal Reconstruction Authority (NRA, 2020). Still, in the rural and mountainous regions where rubble stone remains to be the primary construction material, both these scenarios of qualified design and required approval are highly unlikely to occur. But on a positive note, school buildings in rubble stone 
masonry are currently not completely ruled out in Nepal. This includes even the highest seismic zone with a mapped peak ground acceleration (PGA) of around $0.4 \mathrm{~g}$, as outlined on the new seismic hazard map in the draft version of the updated (and about to be published) seismic code NBC NBC 105:2019 (2019).

Contrary to the 1994 set, the revised NBC 202:2015 makes no distinction between seismic zoning or building categories. It has become a one-size-fits-all publication that does not offer solutions that addresses different seismic hazard levels in the country. It is further noted that both codes (NBC 202 and 203) are nearly identical with regards to the main dimensions, such as building height, openings and reinforcements. NBC 203 for mud mortar is actually more generous by allowing a maximum free wall span of 12 times the wall thickness $(12 \times 0.45=5.4 \mathrm{~m})$ versus $4.5 \mathrm{~m}$ in cement mortar, which seems peculiar. Both codes have a disclaimer on the cover page, stating that "the publication represents a standard of good practice and therefore takes the form of recommendations. Compliance with it does not confer immunity from relevant legal requirements, including bylaws." This makes them indirectly mandatory, but if and how this is enforced, especially in rural areas, is unclear.

\section{India}

The Indian Standard IS:1893 is the main seismic code that deals with the assessment of seismic loads, and which defines the seismic zones and design factors. In the first edition of IS:1893-1962 (1962) the country was divided into 7 seismic zones (0-VI), which was brought to 5 zones (I-V) after the Konya earthquake in 1967 (IS:1893-1970, 1970). This was further merged to the current division of 4 zones (II-V) since IS:1893 (part 1)-2002 (2002), meaning that today all of India is subjected to seismic hazard. Zones IV and V cover most of the Himalayan range such as the states of Arunachal Pradesh, Assam, Sikkim, Uttarakhand, Himachal Pradesh, Ladakh and Jammu, and Kashmir, as well as the Kutch Region in Gujarat in the west; in all these regions stone masonry is still practiced today. Since the very first 1962 edition it is stated that "in highly seismic areas, construction of a type which entails heavy debris and consequent loss of life and property, such as masonryparticularly mud masonry and rubble masonry, is best avoided." For construction features and material specifications the seismic code refers from its earliest editions to IS:4326-1967 (1968) "Earthquake-Resistant Design and Construction of Buildings," IS:1905-1961 (1962) "Masonry Walls" and to IS:1597(part 1)1967 (1967) “Construction of Rubble Stone Masonry." After the 1988 Bihar earthquake in Nepal near the Indian border, more attention was needed for low-strength brickwork and stone masonry. For stone, this resulted in a division between IS:4326-1993 (1993) covering rectangular stone units related to IS:1597(part 2)-1992 (2016) "Construction of Ashlar Stone Masonry"; and a newly introduced code IS:13828-1993 (1993) "Improving Earthquake Resistance of Low-Strength Masonry Buildings," for random rubble stone masonry with cementsand mortar.

Its latest version with amendments IS:13828-1993 (2018) divides all buildings into categories, based on the seismic zonation factor $\mathrm{Z}$ and the building importance factor I. The highest Building Category E requires maximum provisions for strengthening, whereas category A requires the least. The code states that low-strength masonry constructions "should not be permitted" for important buildings with $\mathrm{I} \geq 1.5$. This concludes that school buildings in rubble stone masonry are not allowed to be built anywhere in India, although the word "should" weakens this statement. Houses are not permitted in category E (zone $\mathrm{V}$ ), and "should preferably be avoided" in category D (zone IV). When using cement-sand mortar not leaner than 1:6 and with the inclusion of through-stones in the walls, no special seismic provisions are considered necessary for category B (zone II). As a result for housing designs, seismic specifications only need to be applied in category C (zone III) such as: Maximum building height is 2 stories plus attic, maximum free wall span $5.0 \mathrm{~m}$, maximum floor-to-floor height $3.0 \mathrm{~m}$ and minimum wall thickness $0.35 \mathrm{~m}$. The minimum dimensions for masonry in corners $(230 \mathrm{~mm})$, piers $(450 \mathrm{~mm})$ and maximum percentage of openings ( $46 \%$ in ground floor and $37 \%$ in first story) are more generous than in Nepal, due to the restricted application in zone III only. Horizontal bands must be included at 3 to 4 levels (always roof and lintel, plus gable band on masonry gables, plus plinth beam on soft soils) and vertical bars only at critical wall connections (and in jambs when openings exceed the recommended dimensions). Mortar should be cement-sand in the ratio of 1:6 with minimum compression strength of 3.0 $\mathrm{N} / \mathrm{mm}^{2}$ at 28 days according to IS:1905-1987 (2017), although in IS:13828 even mud mortar is allowed, but with stricter rules for building heights. However, it is important to note that according to the latest seismic code IS:1893 (part 1)2016 (2016), a seismic verification is always required, even in zone II with very low seismicity and a design acceleration factor $\mathrm{Z} / 2=0.05 \mathrm{~g}$.

Like Nepal, the Indian codes are not mandatory from the state level. The current National Building Code of India IS:SP72016 (2016) has incorporated the latest seismic standards, but this code itself indicates that "it is non-statutory in nature and is intended to serve as a model for adoption by Public Works Departments, local bodies and other construction agencies." In urban areas it is nowadays common that banks require certain proof of code compliance to obtain a housing loan, thus giving the Indian seismic codes a status "between desirable and mandatory."

\section{Pakistan}

Pakistan has never had any provisions for stone masonry, nor for low-strength masonry in general, such as in India and Nepal. As early as the Quetta Building Code of 1937 [QBC1937 (1937)], developed after the very heavy and damaging 1935 Quetta earthquake (then part of the British Indian Empire), it is clearly stated that "dry masonry without mortar is strictly forbidden and stone boulders may on no account be used." This statement is repeated in the Quetta Building Rules of 1976 [G.P.(Q)23-3,100-10-77, 1976]. The first Pakistan Building Code BCP-86 (1986) was presented as an "advisory document" and not enforced as a mandatory requirement. After the devastating $2005 \mathrm{Kashmir}$ earthquake, the building code was upgraded with a focus on seismic design of buildings, whilst dividing the whole country into 5 seismic zones (BCP-SP-07, 2007). However, the 
seismic provisions and the masonry chapter are mostly verbatim copies of chapters 16 and 21 of the Uniform Building Code of 1997 (UBC-1997, 1997), meaning that the information does not cover local practices, and as of today is more than 20 years old. The masonry section about empirical design contains wordfor-word copied sections of the Indian Standards IS:4326-1993 (1993) and IS:1905-1987 (1989), which are specifically meant for regular sized stones (Ashlar), and currently more than 30 years old. Interestingly, rubble stone masonry of minimum $400 \mathrm{~mm}$ thickness with the inclusion of through-stones is specifically mentioned in chapter 2109.10 of UBC-97. Therefore, it is surprising that of all articles this one was not copied into the Pakistani code. Even better would have been the inclusion of IS.13828 for low-strength masonry, as stone is still widely used in the northern parts of the country, especially in Gilgit-Baltistan province. In 2015 it was estimated that roughly 5\% of the total building stock of Pakistan continues to be built with stone (Lodi, 2015), which is around 1.25 million units, mostly located in the Karakoram mountain range which is part of the TransHimalayan region. If Pakistan has deliberately excluded rubble stone masonry from their code, then it must be questioned whether this represents the current practices and actual needs, at least for a significant part of the country. With that, the code also excludes other interesting traditional techniques, such as "Bhatar" which consists of dry-stacked loadbearing stone walls with horizontal timber lacing (Carabbio et al., 2018), or "Dhajji Dewari," wooden loadbearing frames with stone infill (Hicyilmaz, 2011). Structurally both systems behave different than nominally reinforced loadbearing masonry, but these techniques have resisted the 2015 earthquake very well.

\section{Afghanistan}

A 2003 governmental-issued construction manual estimated at the time that "more than $90 \%$ of the country's building stock are non-engineered constructions, made of mud-bricks and stone" (MUDH, 2003). No recent figures were found, but stone masonry is still abundantly practiced all over Afghanistan, such as in the seismically active Hindu Kush mountain range. Due to decades of conflict and a lack of governmental regulatory systems, Afghanistan did not have a unified building code until 2012 and engineers freely used locally issued guidelines and (former) Soviet and Indian codes, such as 1982-102-1 (1982) and 19837-II (1983), which were partial translations of the Russian code SNiP II-A.12-69* (1977) and the Indian code of practice IS:43261976 (1977). These allowed buildings up to $8 \mathrm{~m}$ height in seismic Intensity zone 8 , for masonry category 3 which includes irregular shaped stones (explained in more detail in the "Russian" section). The first mandatory Afghan Building Code (ABC-2012, 2012), however, is basically a collection of literally copied segments of the US codes IBC-2009 (2009) for structural requirements, ASCE/SEI-7-10 (2010) for design loads, and refers to ACI 530/530.1-11 (2011) for masonry. The masonry chapter defines that stone masonry units must conform to ASTM C568/C568M (2015) for limestone, ASTM C615/C615M (2018) for granite and ASTM C616/C616M (2015) for sandstone units. As these standards are exclusively for dimensioned stone, the Afghan code completely rules out the use of rubble stone for building purposes, which does not serve the current (non-engineered) construction needs and practices in the country.

\section{China}

China has a long historic culture of stone masonry which has been practiced for many centuries. For instance, Xizang Province (Tibet) borders the Himalayan Range, and Xinjiang Province is crossed by the Altay, Tian Shan, Kunlun Shan and Karakoram Mountains. China has also been prone to some of the most devastating earthquakes in history. Before the 1974 trial version of the first Chinese seismic code, China mainly followed the Russian codes. The country is divided into Seismic Fortification zones, and every building in zone 6 or above must be designed to resist earthquake motions. The earliest codes such as TJ 11-78 (1979) did not cover stone masonry, but all revisions that followed, starting with GBJ 11-89 (1993), have included a separate chapter with sections for earth, wood and stone buildings, which is still included in the most recent seismic code GB 50011-2010 (2016).

China uses a variety of stone types for masonry, as clearly explained in the "Standard for Building Material in Villages and Towns" (CECS 317:2012, 2012). It distinguishes four types of Ashlar with different degrees of dressing, being fine, semi-fine, coarse and very coarse. It further categorizes two types of rubble stone; flat rubble stone, which is minimum $150 \mathrm{~mm}$ thick and has two sides that are roughly parallel, and irregular rubble stone. The latter is prohibited for constructing buildings in seismic areas, and so are round river boulders.

Regarding building typology, Standard GB/T 33735-2017 (2017) for "Avoiding Earthquake Danger for Schools" refers to the National seismic code GB 50011. However, its section for stone only covers low-rise buildings in ashlar masonry with concrete floors, meaning that rubble stone masonry buildings (with wooden floors) are ruled out. Along with that, school buildings in stone masonry are not allowed in any case due to certain design specifications for classrooms and requirements for indoor environment, as dictated in the "Code for Design of Schools" (GB 50099-2011, 2010). Further, the minimum demand for daylight in classrooms is specified in the design regulation for rural school buildings (Construction Standard 109, 2008), recommending a minimum ratio of glass surface versus floor area of 1:6. This results in too large openings which exceed the limitations of stone walls (and of general masonry walls as well). For all the above reasons, schools in China are currently predominantly constructed with reinforced concrete frames.

For houses on the other hand, China has published a "seismic technical specification" for construction of buildings in rural towns and villages (JGJ 161-2008, 2008). In this code, flat rubble stone houses with wooden roofs are allowed up to one story in zone 7 , with a maximum height of $3.6 \mathrm{~m}$ from ground level to halfway the gable. Minimum wall thickness is $400 \mathrm{~mm}$, maximum cross-spacing of walls $11 \mathrm{~m}$, and minimum lengths of corner masonry and piers are $1 \mathrm{~m}$. The total length of openings should not exceed $25 \%$ in cross-walls with a maximum length of $1.5 \mathrm{~m}$ per opening, and $50 \%$ in longitudinal walls with a maximum of $1.8 \mathrm{~m}$. Reinforced concrete tie-beams must be included on top of the foundation and at roof level, as well as steel bar stitches 
in corners and junctions at $500-700 \mathrm{~mm}$ intervals. The code further details specific connections between elements, stiffening of the roof structure, and laying patterns of the stones. China has developed a National Atlas of building designs, including a chapter with plans, sections and details of stone houses, that follow all the above-mentioned seismic design rules, material specifications and construction guidelines (08SG618-4, 2008).

\section{Rubble Stone Masonry in Central Asia and the Caucasus}

The countries stretching from the borders of China toward the Black Sea all belonged to the former Soviet Union and include areas with severe seismicity. Central Asia consists of five states known as "the Stans" which are Tajikistan, Kyrgyzstan, Turkmenistan, Uzbekistan, and Kazakhstan, of which the main mountain ranges are shown in Figure 2. The Caucasus includes Russia, Azerbaijan, Georgia, and Armenia. Until the dissolution of the Soviet Union in 1991, all countries followed the State standards (GOST) and the unified system of mandatory Construction Rules and Regulations (SNiP), sometimes with the addition of Regional Norms. After 1991 these countries started developing their own regulations, although most are still very similar to the Russian codes and are published bi-lingual (local language and Russian). The seismic rules apply to the design of buildings and structures at sites with seismicity of 7, 8, and 9 points, as defined on national seismic hazard maps that are based on the MSK-64 intensity scale (Medvedev and Sponheuer, 1969), although some countries have switched to a probabilistic seismic hazard analysis approach (Armenia, Kyrgyzstan).

\section{Russia}

To understand the role of stone masonry in all (former) Russian territories, one needs to go back to the definitions in the earliest codes of the 1950s. The material code SNiP I-A.1 (1955) makes a clear distinction between natural stones for wall masonry, being "stones of the correct form" such as sawn, chipped or cut shell limestones, and volcanic tuffs and other local light rocks with standard sizes; versus "pieces of irregularly shaped rubble stone from local rocks" such as limestone, dolomites or sandstones. The subsequent material code SNiP I-B.8-62 (1962) further explains that "flattened or broken stone" (rubble) is obtained from either direct splitting of boulders, or by sorting of fractions from blasted rock. It further states that "for above-ground walls, sawn and chipped wall stones of the correct form are used. Rubble stone is allowed for masonry walls of agricultural, non-residential and industrial buildings."

In the seismic codes this is reflected as follows. Until the 1970s all masonry was divided into four strength classes. Rubble stone masonry was explicitly mentioned, as in PSP 101-51 (1951) which ranks the use of "natural stone of irregular shape" in categories 3 and 4, depending on mortar type. Category 3 masonry must meet a minimum "ultimate axial tensile strength" of $60 \mathrm{kPa}$, and category 4 at least $30 \mathrm{kPa}$. The next code SN 8-57 (1958) adds that for buildings in areas with estimated seismicity of 8 and 9 points, it is recommended to use masonry weighing no more than $1,900 \mathrm{~kg} / \mathrm{m}^{3}$ (this includes most types of sawn stones); whereas masonry above $1,900 \mathrm{~kg} / \mathrm{m}^{3}$ goes down one category (basically all types of rubble stone). This means that from an early stage, the codes refer to the lighter stone masonry types consisting of units with rectangular shapes. In 1969 (SNiP II-A.12-69*, 1977) masonry is reduced to just 3 categories, but still with an explicit mention of rubble stone.

Since the 1981 edition (SNiP II-7-81*, 1989) until today just 2 categories remain, with strengths over $180 \mathrm{kPa}$ and between 180 and $120 \mathrm{kPa}$. For natural stone units, only "stones or blocks made of shell rock, limestones or tuffs" are allowed, but without any description of the shape or dimensions. These requirements were described in the State Standard GOST 4001-66 (1967), for sawn wall stones with "a rectangular parallelepiped shape with straight edges and regular faces." Therefore, and with the older codes in mind, we must assume that the 1981 seismic clauses refer to dimensioned stones only, and that rubble stone masonry is no longer allowed in the Russian seismic codes since. But in fact, this is no longer clearly described or specifically mentioned.

It is noteworthy that the earliest codes of the 1950s and 1960s had included a quite elaborate chapter about rural construction with earthen materials, which is still present in most recently updated seismic code SP 14.13330.2018 (2018). Unfortunately, the technique with rubble stone was never added to these clauses. On the other hand, the most recent and updated version of GOST 4001-2013 (2014) for natural stones has reintroduced rubble stone for the first time since the 1980s, but so far this has not lead to a renewed attitude toward rubble stone masonry in the seismic nor masonry codes. Similar to China, schools are not allowed these days due to specific requirements for comfort and daylight, but since these regulations were introduced only recently (SP $52.13330 .2016,2017)$, the codes in the former Russian states do not refer to such rules yet. The following paragraphs explain how the former Soviet countries deal with stone masonry today, except for Kazakhstan where this technique traditionally was not used.

\section{Tajikistan}

Tajikistan is extremely mountainous, with mountains covering $93 \%$ of its surface, of which more than half are situated above 3,000 m. Centrally located are the Pamir Mountains and all borders are surrounded by mountain ranges, such as the Hindu Kush with Afghanistan, Tian Shan with China, the Alay Mountains with Kyrgyzstan, and the Turkestan Range with Uzbekistan. Around 70\% of the population lives in rural and mountainous areas, where the main construction type consists of self-built single-family houses in stone or mud-bricks (UNECE, 2011). The whole country has a very high seismic risk and Tajikistan is mapped in just 3 intensity zones of 7, 8, and 9 points. Contrary to the Russian and most neighboring codes, the masonry chapter of the first post-Soviet Tajik seismic code MKS CT 22-07-2007 (2007) does not explicitly rule out rubble stone, as it only "recommends" that stones must be of regular shape. With this minor adjustment stone masonry is allowed, even in the highest risk zone of 9 points. Still, lower-strength masonry of category 2 must meet a minimum "ultimate axial tensile strength of $120 \mathrm{kPa}$," which may be difficult to determine (or understand) in the rural areas. For zone 9 (on average soil) the code describes maximum building dimensions of $45 \mathrm{~m}$ length and 2 stories height, and maximum $9 \mathrm{~m}$ between cross-walls, 
which is far more generous than the Asian codes. Maximum width of openings is $2.5 \mathrm{~m}$, minimum lengths for corner masonry is 1.8 and $1.55 \mathrm{~m}$ for piers, whereas the length of openings versus length of a wall may not exceed $25 \%$. Wooden floors are allowed and the code further describes the inclusion of a continuous reinforced concrete band at floor or roof level, and wire mesh reinforcements in the horizontal joints at certain intervals, whilst vertical reinforcements are recommended and only mandatory in designs with complex plan configurations.

\section{Kyrgyzstan}

Kyrgyzstan is also characterized by a mountainous landscape, with roughly two-thirds of its population living in the rural and mountain areas. The housing stock mainly consists of single-family masonry buildings, mostly in adobe construction (Pittore and Parolai, 2016). Although figures were not found, it is expected that stone masonry is still practiced in the Tian Shan Mountain range at the border with China and the Alay and Turkestan ranges near Tajikistan, although to a lesser extent compared to Tajikistan. Kyrgyzstan had developed its first national seismic code in 1994 based on the Russian code and revised it twice. The 2009 version SNiP KR 20-02:2009 (2017) only allowed masonry that is reinforced with horizontal and vertical concrete elements, without specifying stone materials. However, the latest 2018 revision SN KR 20-02:2018 (2018) only allows stones of regular shape, thus ruling out rubble stone masonry. It is further noted that for determination of seismic loads, Kyrgyzstan has switched to calculation models that follow Eurocode. Kyrgyzstan is subject to a very high seismic hazard with estimated PGA $>0.6 \mathrm{~g}$.

\section{Turkmenistan}

Turkmenistan has a high seismic risk at its border with Iran. Roughly half the population lives in rural areas (World Bank, 2020), but no recent data was found on construction practices in those regions. Traditionally, adobe and earthen structures were most common, with some sporadic examples of stone masonry in the Köpet Dag Mountains. The masonry chapter in the first Turkmen seismic code SNT 2.01.08-99 (2000) is nearly identical to the Russian code of 1981, which does not cover rubble stone. However, one clause allows one-story buildings in rural settlements in zone 7 to be built with adobe, soil blocks and "other low-strength materials." Possibly for these, the code has included the third strength-category for masonry (between 120 and $60 \mathrm{kPa}$ ). The appendix with building classifications defines type $1 \mathrm{~b}$ as "houses with walls made of earthen bricks or rubble stone, with a light wooden roof," although no further details or dimensions are given. Further, when constructing on rock soil, the design class goes down with one point from intensity zone 6 to 7 , for which no seismic verification is required.

\section{Uzbekistan}

In Uzbekistan around half of the population lives in rural settings, such as the mountainous areas bordering Kyrgyzstan and Tajikistan, which have a high seismic risk. Here, the main traditional materials for construction are adobe and stone, for self-built privately owned houses (Kaufmann et al., 2004), and also for school buildings (Nurtaev et al., 2017). The masonry chapter of the first post-Soviet seismic code KMK 2.01.03-96 (2004) mentions only the lighter natural stones types of shell rock, limestones or tuff, and explicitly mentions these must be of regular shape. However, in the 2004 amendment an extra clause is added to the separate chapter for "low-rise buildings with low-strength materials" such as adobe and wood: "For the construction of one-story buildings it is allowed to use natural stone with anti-seismic measures, developed according to special technical conditions agreed upon by the State Architects of the Republic of Uzbekistan." Uzbekistan is working on a revision of their seismic code which is expected to be published in 2020. Hopefully, this updated version will include these technical details, and addresses constructions in rubble stone according to the current needs in the mountainous areas of the country.

\section{Azerbaijan}

Roughly $60 \%$ of the surface of Azerbaijan is covered by mountains, such as the Greater and Lesser Caucasus Ranges and the Talysh Mountains bordering Iran. All mountain ranges of the Caucasus are shown in Figure 3. The country is assigned to just 2 very high seismic hazard levels; intensity zones 8 and 9 . Traditionally, stone masonry has been practiced widely with many examples of complete villages built with stone walls and wooden reinforcements. It is expected that the technique is still practiced in the rural and mountainous areas in Azerbaijan and the Nakhchivan Autonomous Republic. However, the first seismic code AzDTN 2.3-1 (2014) does not reflect this culture as the masonry chapter is an almost identical copy of the 1981 Russian seismic code, which only describes dimensioned stone. No specific or extra clauses are added for rubble stone masonry.

\section{Georgia}

Georgia is wedged in between the Greater Caucasus Mountains on the borders with Russia and Azerbaijan, and the Lesser Caucasus Range on the southern border with Armenia. The country still has a rich culture of stone masonry that is reflected in their first National seismic code PN 01.01-09 (2012), which includes a separate chapter for buildings made of local materials. In here, rubble stone buildings of 2 stories height are allowed in seismic zone 7 and 8 , with a maximum cross-wall spacing of 6 $\mathrm{m}$. (This contradicts a previous table which allows 2 stories in zone 7 , and 1 story in zones 8 and 9 as well). Walls must be strengthened with 2 horizontal rows of bricks for every $60-80 \mathrm{~cm}$ wall height, and a continuous tie-beam at floor level. Floors must be made of wooden members, the roof structure must be properly anchored to the walls and made as stiff as possible. No further dimensions are given in this section, however, if we follow the general masonry chapter this results for zone 8 in a most generous maximum length of $80 \mathrm{~m}$ between separate building units. Bearing in mind the original Russian codes, it is likely that these dimensions are meant for regular masonry with dimensioned stone, and not for rubble stone masonry. Dimensions for corner masonry, piers and openings are exclusively mentioned for brick masonry; for stone masonry verification through calculations is 
needed. A minimum wall thickness is also not mentioned, but traditionally rubble stone masonry walls in Georgia are between 60 and $80 \mathrm{~cm}$ thick. The minimum strength requirement for cement-sand mortar is grade 25 for normal conditions and grade 50 in areas subject to temperatures below $0^{\circ} \mathrm{C}$. Grade 25 means an ultimate compression strength of $25 \mathrm{~kg} / \mathrm{cm}^{2}$ which roughly equals M2.5 mortars (2.5 MPa).

\section{Armenia}

Armenia also has a rich historic culture of stone masonry, which is still practiced today. Roughly one-third of Armenia's dwellings are in the rural and mountainous areas. Most of these mainly single-family houses are built with volcanic or dressed tuff stones, the traditional building material of Armenia (UNECE, 2017). The sawn stone types as mentioned in the Russian codes since the 1950s often come from Armenia, such as Arctic, Ani, and Yerevan tuff. Since medieval times $50 \mathrm{~cm}$ thick loadbearing walls were built of a stone cladding type called "Midis," with a double layer of roughly cut stones, filled with mortar and pumice in the middle. The technique is still explained in the masonry code RABC IV-13.01-96 (1996), in which also standardized sizes and wall thickness between 19 and $39 \mathrm{~cm}$ are mentioned for fully dressed stones, as mainly used today.

The third-and-about-to-be-published (as of September 2020) version of the Armenian seismic code RABC 20.04_ (2020) has become more conservative toward masonry in general, compared to its predecessor RABC II-6.02-2006 (2011). The code divides the country in 3 seismic zones (1-3) and distinguishes four soil types (profiles I-IV). The masonry chapter is quite different from the Russian code and specifically allows rubble stone masonry. For type III structural loadbearing masonry with horizontal (steel net) reinforcements, no difference is made between bricks, dimensioned stones or rubble stones, for as long as a minimum wall strength requirement $(120 \mathrm{kPa})$ is met. In the most unfavorable scenario (zone 3 , soil profile IV) for masonry type III, a maximum building ratio of 1:3 (width versus length) is allowed, with a limitation of 2 stories height and $6 \mathrm{~m}$ spacing of cross-walls. The maximum width of openings is $2.0 \mathrm{~m}$, corner masonry has a minimum length of $2.5 \mathrm{~m}$ and piers minimum $2.2 \mathrm{~m}$. Horizontal concrete bands at floor level are mandatory, but as floors must act as rigid diaphragms, wooden floors are not allowed. This latest revision specifically adds that for school buildings, only monolithic concrete slabs are allowed. All other rules apply for both houses and schools, although a recent guideline (not mandatory) for restauration and new construction of school buildings, recommends only reinforced concrete and steel frame structures (Applied Technology Council, 2017). It must be further noted that, although rubble stone is allowed, it is not used very often, as in Armenia the primary choice for stone wall material is dimensioned tuff stone blocks.

\section{Rubble Stone Masonry in the Middle East}

Most countries bordering or located on the Arabian Plate are either subject to relatively low seismicity levels, or they mainly follow international seismic codes. For instance, the Lebanese code NL-135 (2012) refers to either the French or US-based codes (but intends to adopt Eurocode), the Syrian code is basically a translation of UBC-97 (SAC-2012-2, 2013), Israel goes with ASCE-7 (SI-431-1995, 2013), Iraq embraces the 2012 International Building Code (IBC) (ISC-303, 2017) and Oman largely follows Eurocode (OSDC-2013, 2013). In Jordan, a very common wall system for low-rise buildings consists of veneer-like cut stone blocks that are back-filled with plain concrete, and confined with horizontal and vertical reinforced concrete elements; but structurally this is a different type of construction than NRM (Al-Nimry et al., 2003). In Saudi Arabia stone was used a lot in the past, such as in the southern provinces of Saheer and $\mathrm{Al}$ Bahah, but these days it is basically no longer practiced. They mainly follow IBC and mention in its masonry code that stone masonry is only allowed in their lowest Seismic Design Category A (SBC 305Cr, 2018) with very low seismic risk $(<0.07 g)$. Yemen, with its rich history of stone and earth block masonry, does not have a seismic nor masonry code at all. Therefore, the two remaining countries of interest in this region are Turkey and Iran. The main mountain ranges of the Middle East are shown in Figure 3.

\section{Turkey}

Turkey has a long and rich history of construction using stone masonry, such as fully loadbearing walls with wood-lacing, or a system of braced wooden frames with stone-infill called "hımış." The country is frequently subjected to destructive earthquakes. The first provisional Turkish seismic code, published after the devastating 1939 Erzincan earthquake, was basically an adapted translation of the 1937 Italian code (RDL n.2105, 1937). The second edition ZMMYT-44 (1944) allowed two-story uncut rubble stone buildings with a maximum length of $12 \mathrm{~m}$ and wall thickness at ground floor of $60 \mathrm{~cm}$ and first floor of $35 \mathrm{~cm}$, along with nominal required reinforcements. Interestingly, in the 1968 version ABYYHY-68 (1968) the building height was increased to 3 stories, but then again 7 years later this was drastically reduced to just one floor (ABYYHY-75, 1975). The rules for stone remained the same until the code of 2007 (DBYBHY, 2007), but since the most recent revision of 2018, rubble stone masonry is no longer allowed (TBDY, 2018). The masonry chapter refers to the European norms and TS EN 771-6+A1 (2015) in particular, meaning that natural stone units must follow the requirements for dimensioned stones. On top of that, it is emphasized that rubble stone, among other materials like pumice and adobe, "shall not be used as bearing wall material." This is unfortunate, as reconnaissance reports show that rural one-story stone houses with traditional nominal reinforcements and light roofs behaved well under seismic motion, such as during the 2003 Bingöl (Ozcebe et al., 2003) and 2011 Van-Erciş earthquakes (Aydan et al., 2012).

\section{Iran}

Iran is situated in a very active part of the Alpine-Himalayan seismic belt. Almost the whole country, including several large mountain ranges, such as the Alborz, Zagros, Makran, and Köpet Dag Mountains, falls within an active seismic zone numbered 1-4 on the Iranian seismic hazard map (Moinfar et al., 2012). Due to the predominant use of Unreinforced Masonry (URM) 


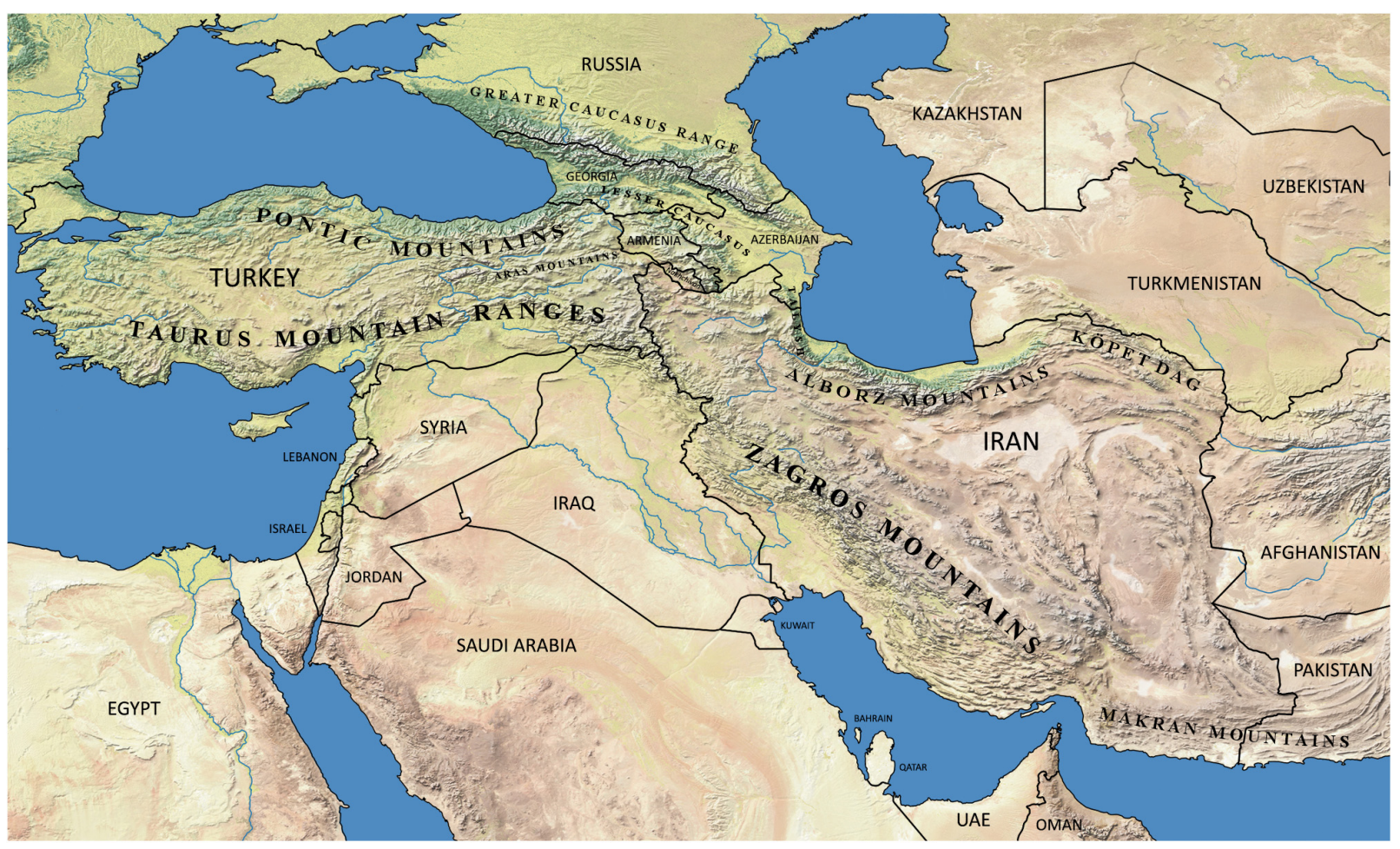

FIGURE 3 | Main mountain ranges of the Caucasus region and the Middle East (original source: Natural Earth raster + vector map).

construction at that time, the first Iranian seismic code PBO64 (1964) covered only "non-engineered" buildings such as loadbearing masonry with additional horizontal tie-beams. The first edition of the modern Iranian seismic code Standard 2800 (1987) made a clear division between engineered buildings (steel, concrete) and introduced a separate chapter for URM. The information in this chapter remained nearly identical for 28 years, but in the most recent fourth edition Standard 2800 (2015) it is renamed to "Provisions for Masonry Buildings with Ties." The chapter solely describes Confined Masonry with some alternatives for materialization including confined rubble stone masonry, which is achieving promising test results (Ahmadizadeh and Shakib, 2016).

Unreinforced masonry (or in this case URM but nominally reinforced) with cement mortar and a wooden roof is described in the Iranian masonry code NBRI-8 (2013). It allows rubble stone but only in the lowest seismic zone (PGA $\leq 0.20 \mathrm{~g}$ ), for buildings of maximum one floor above ground level with $3.5 \mathrm{~m}$ height. The minimum wall thickness is $450 \mathrm{~mm}$ and the building length may not exceed 2 times its width (or $25 \mathrm{~m}$ ), with maximum $4 \mathrm{~m}$ cross-spacing of walls. Openings may not exceed $1.2 \mathrm{~m}$, piers must be minimum $650 \mathrm{~mm}$ and corner masonry must be at least two-thirds of the height of the adjoining opening. One horizontal tie-beam is required at roof level, and vertical reinforcements are not necessary when all the above-mentioned dimensions are respected. Interestingly, for both URM (NRM) and CM, no seismic verifications are needed according to the Iranian seismic code. Moreover, neither seismic nor masonry code makes a difference between buildings of medium (houses) and high importance (schools). However, it must be noted that all schools are designed and constructed by the "Organization of Renovation, Development, and Equipping of Schools" under the Ministry of Education, who is in a position to deviate from the codes, and may apply different (possibly stricter) regulations for the urban or rural settings.

\section{Rubble Stone Masonry in Northern Africa}

Most of the African Continent has very low seismicity, to basically no activity across the Sahara and central parts. However, some northern countries that border the Mediterranean Sea are subject to significant earthquake risks. Tunisia and Libya have not yet developed national seismic codes up to date. Due to 130 years of French colonial rule, they mostly follow the older French codes such as DTU Règles-PS-92 (2004), which mentions both cut and rubble stone as a possible masonry material, but only for Confined Masonry structures. The Egyptian building code solely describes the use of dimensioned brick and block-shaped stones (ECP-204, 2005). The main mountain ranges of Northern Africa are shown in Figure 4.

\section{Algeria}

Algeria has possibly published the first seismic code ever, with regulations for reconstruction as ordered by Governor (Dey) Ali Chaouch after the 1716 Algiers earthquake (Chesneau, 1892). After the 1954 Chlef earthquake, a provisional set of recommendations was published (AS55, 1955) which described 


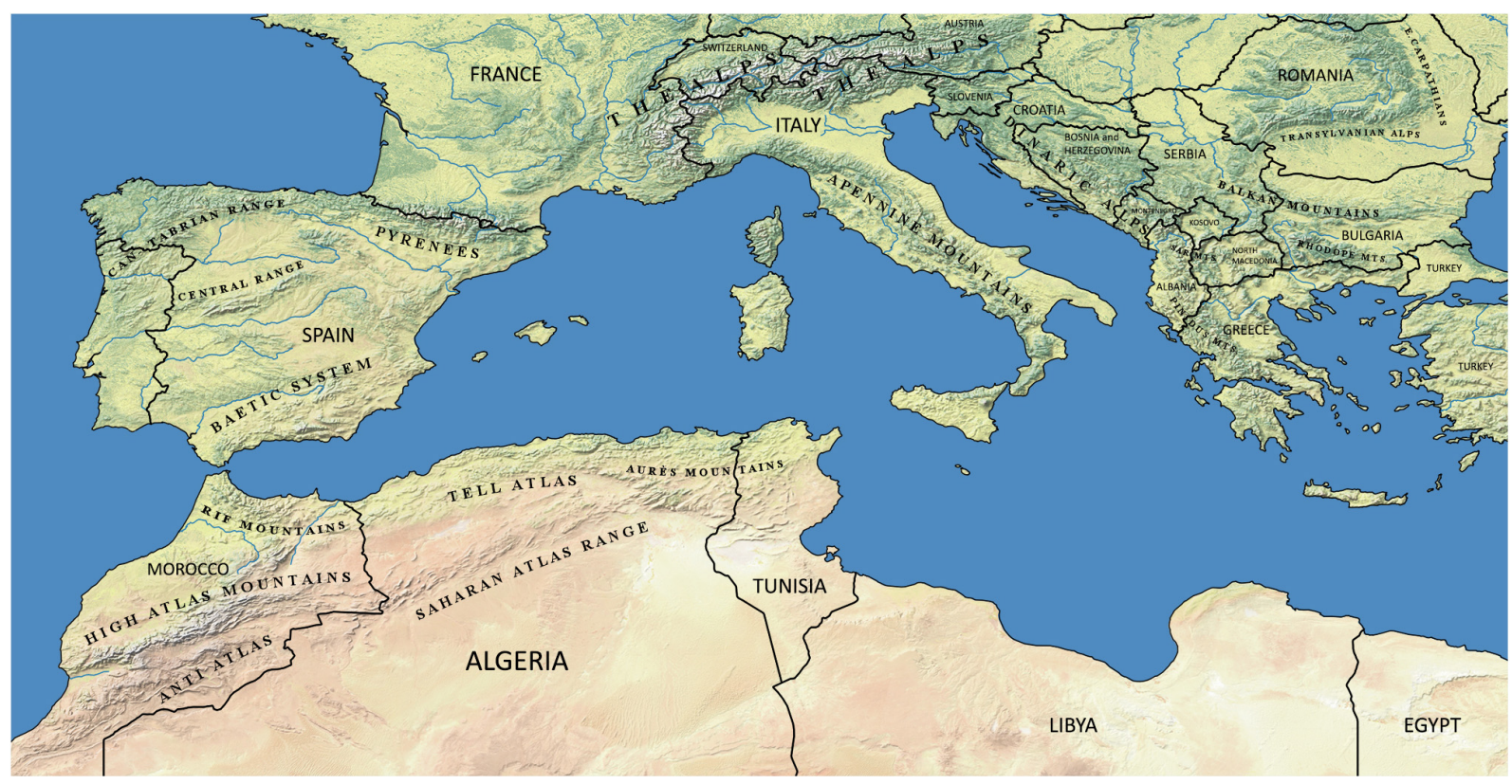

FIGURE 4 | Main mountain ranges of North Africa, East and South Europe (original source: Natural Earth raster + vector map).

the use of Confined Masonry for seismic areas, but without materialization of the masonry units. It was followed by the French code DTU Règles-PS-69 (1970) with similar recommendations. After the destructive El Asnam earthquake in 1980, Algeria published its first national and mandatory seismic code (RPA-81, 1981). It was revised in 1999 and directly amended after the very damaging 2003 Boumerdes earthquake into the current version RPA-99 (2003), which does allow rubble stones; but only for Confined Masonry buildings, up to 3 stories in the highest seismic zones III and IIB, and 5 stories in zone I.

\section{Morocco}

Morocco published a local code right after the highly devastating Agadir earthquake in 1960 (Normes Agadir-1960, 1960), which allowed only confined rubble stone masonry for buildings up to 4 stories. The code included very detailed descriptions for types and dimensions of stones and masonry patterns. In their latest code RPS-2000 (2011) rubble stone masonry with cement mortar is allowed in three techniques (URM, CM, RM), all with a maximum of 2 stories regardless of the seismic zoning. For URM unfortunately, no further dimensions nor details are given, in contrast to a separate code that Morocco has published for earthen structures in seismic areas, as "this cultural heritage has great aesthetic quality and remarkable adaptation to climatic conditions" (RPCTerre-2011, 2013). It resembles the Nepali and Indian codes for NRM, however, it only covers rubble stone with mud mortar. Lastly, it is important to note that nearly all of Morocco (except Al Hoceima in the north and Agadir in the south) has low to very low seismic risk levels (Cherkaoui and El Hassani, 2012). This almost negligible risk includes the complete Atlas Mountain ranges, where stone masonry is still broadly utilized.

\section{Rubble Stone Masonry in Europe}

Since 2004, the European seismic code EN 1998-1:2004+A1 (2013), commonly known as Eurocode 8, is the leading norm to which most European countries have committed. It describes a minimum required thickness of $350 \mathrm{~mm}$ for URM shear walls with natural stone units, but only for moderate seismicity zones with an acceleration value $\mathrm{a}_{\mathrm{g}, \mathrm{urm}} \leq 0.20 \mathrm{~g}$, and with the addition of horizontal and vertical reinforcements (making it NRM). It refers to the masonry code Eurocode 6 (EN 1996-1-1, 2005) for specifications of the masonry units, which dictates that only dimensioned stones are acceptable, as further specified in EN 771-6:2011+A1 (2015) for "Natural Stone Masonry Units." This means that Eurocode clearly prohibits the use of newly built squared rubble and random rubble stone masonry structures in seismic areas. Countries that have adopted Eurocode are, however, allowed to deviate from the regulations through their National Annexes. The following paragraphs describe the historic application of stone masonry in the seismically active Eastern and Southern regions of Europe (Figure 4) and examines if countries currently allow rubble stone as a masonry material.

\section{Romania}

In their first seismic code P13-63 (1963) Romania mentioned the use of irregular shaped natural stones with cement-lime mortar for masonry, although its use was limited to ground floor buildings only. But after the powerful 1977 Vrancea earthquake, the use of stone for walls has been removed altogether from the seismic code P100-78 (1978) and masonry code P2-85 (1985) ever since. With that omission, a very nicely illustrated technical publication from 1979, one of very few manuals worldwide that was specifically drafted for stone masonry, became void as well (C193-79, 1979). Also the most recent seismic code of 
2013, which is harmonized with Eurocode 8, explicitly excludes stone masonry and explains this in the commentary as follows: "For stone masonry special regulations are required because the existing information, necessary for the seismic design, is incomplete or irrelevant. Experimental research is necessary and important, both at the level of the respective elements and the structural elements of this type of masonry" (P100-1, 2013). This means that on a positive note, further research may create new opportunities for stone masonry in the future.

\section{Bulgaria}

In Bulgaria lots of stone masonry is still seen, such as in the Rhodope Mountains, a region subject to high seismic levels. The first Bulgarian seismic code Decree n.15 (1947) allowed stone masonry for two-story buildings in the highest seismic zone IX, with a minimum wall thickness of $53 \mathrm{~cm}$ and maximum wall-spacing of $12 \mathrm{~m}$, but without specification for the type of stones. The following code State Committee for Construction and Architecture (1957) specified that natural stones must be of regular shape (Ashlar) and this requirement has not changed up to the latest Bulgarian seismic code Ordinance RD-0220-2 (2012), which only describes certain brick types for use as masonry unit. This current code is strongly influenced by Eurocode 8 but remains to be the main seismic code used in Bulgaria, as Eurocode 8 is only mandatory for structures of very high and national importance.

\section{Former Yugoslavian Countries}

Until the dissolution in 1992 into its currently 7 independent countries (Slovenia, Croatia, Bosnia-Herzegovina, Montenegro, Serbia, Kosovo, and North Macedonia), the whole region used one unified seismic code with the addition of regional seismic hazard maps. After the very damaging 1963 Skopje earthquake in Macedonia, a temporary code SFRY-39/64 (1964) was drafted. It mentioned a few specifics for irregular stone masonry, such as a maximum height of 2 stories, and that the masonry must be reinforced or confined. After the 1979 Montenegro earthquake, the new code SFRY-31/81 (1981) was published. It was revised several times and new seismic maps for all regions (based on the MSK-64 intensity scale) were introduced in its latest version SFRY-52/90 (1990). It distinguishes three types of masonry: Ordinary (meaning Unreinforced), Confined and Reinforced. Ordinary masonry considers walls that are constructed with bricks, burnt-clay blocks or "other materials," with either cement-sand-lime or cement mortar with a minimum compressive strength of $2.5 \mathrm{MPa}$. All walls thicker than $19 \mathrm{~cm}$ must be strengthened with horizontal tie-beams and vertical tie-columns, and floors must be rigid concrete slabs (or of equivalent stiffness). Although stone is no longer specifically mentioned, the code states that masonry must meet certain tensile strength requirements, if needed by proof of experimental testing. Provided that stone, or even rubble stone is allowed as "other material," then 2-story buildings with spacing of $7.5 \mathrm{~m}$ between cross-walls of $38 \mathrm{~cm}$ thickness are allowed in seismic zone VIII, without further calculations and regardless of the masonry type. With seismic verifications, confined masonry is allowed up to 3 floors in zone IX and 4 floors in zone VIII.
Currently, Bosnia-Herzegovina, Montenegro, Kosovo and North Macedonia are still in the process of adopting and implementing the Eurocodes (Athanasopoulou et al., 2019), therefore the 1981 version of the Yugoslavian code (plus revisions) is still valid in these countries. On the other hand, Croatia, Slovenia and recently also Serbia (RS-89/2019, 2019) have fully adopted the Eurocodes; the latter two without anything specific in their annexes for stone masonry, thus only allowing Ashlar stone masonry.

\section{Croatia}

Croatia deserves a separate section, being the only country in this region that has conducted research on the mechanical properties of stone masonry, as mentioned in the Yugoslavian code. As a result, it has added "roughly cut stone" with a minimum wall thickness of $450 \mathrm{~mm}$ and minimum compression strengths for stone $\left(30 \mathrm{~N} / \mathrm{mm}^{2}\right)$ and mortar $\left(5 \mathrm{~N} / \mathrm{mm}^{2}\right)$ to its National Annex of Eurocode 6 (HRN EN 1996-1-1:2012/NA, 2012). When following their annex to Eurocode 8 (nHRN EN 1998-1:2011/NA, 2011) for URM with required nominal reinforcements, then "simple masonry buildings" in importance class II (houses) are allowed without mandatory verification, as follows: Maximum height depending on the acceleration at site (2 stories for $a_{g}$ $=0.30 \mathrm{~g}$ or 5 stories for $\mathrm{a}_{\mathrm{g}} \leq 0.20 \mathrm{~g}$, both on rock soil) and $\mathrm{a}$ minimum given percentual area of shear walls. These values are more generous than the recommendations in Eurocode 8 itself. The length of a building between seismic gaps may not exceed 4 times its width, with a maximum spacing of cross-walls of 7 m. Dimensions of wall elements (l) next to openings (o) must conform to a ratio of $1 / \mathrm{h}(\mathrm{o})>0.5$, which roughly amounts to $1,050 \mathrm{~mm}$ next to doors. As stated at the beginning of this European section, Eurocode 8 recommends that URM is not used when the acceleration at site $\left(a_{g}\right.$,urm $\left.=a_{g} \cdot S\right)$ exceeds $0.20 \mathrm{~g}$. Croatia has not defined such limit in their Annex, however, for buildings with higher importance such as schools, and URM buildings in areas with PGA $>0.30 \mathrm{~g}$, a full seismic verification is required. In all cases, URM must be strengthened with a horizontal tie-beam at floor and roof level, and a floor type that provides adequate diaphragm action.

\section{Albania}

Albania is particularly interesting, as stone was not only used in the past, it is still practiced today at various places in the Northern and Southern Mountain Ranges. Their 2011 census showed that $88 \%$ of the countries' building stock consisted of brick or stone masonry (Novikova et al., 2015). Although Albania has adopted Eurocode, these regulations are not yet implemented. The translation of Eurocode 8 (RRTP-NRT-2004, 2014) states that its rules must be used in conjunction with the Albanian seismic code KTP-N.2-89 (1989), which may cause confusion as it is largely Russian-based. Effectively, most engineers still use the 1989 Albanian version. Its predecessor KTP-2-78 (1978) did allow masonry with irregularly shaped rubble stone in seismic zone 7 , with a maximum building length of $10 \mathrm{~m}$ and height of $5 \mathrm{~m}$. The 1989 code, however, has introduced building importance classes and only allows irregular stone masonry for small industrial and agricultural buildings, but no longer for schools and houses. 


\section{Greece}

Greece is seismically one of the most hazardous regions of Europe, with a rich history of stone masonry. Their first seismic code BD-19/02 (1959) makes just one mention of "artificial or man-made natural stone," but without further detail. Greece never had a separate masonry code, and also their latest seismic code EAK2000 (2010) does not mention stone masonry. In 2014 Greece has decreed that for seismic design of buildings, either AEK2000 or Eurocode 8 is used (Decree 372-30.5.2014, 2014), which effectively rules out new applications of rubble stone masonry buildings.

\section{Portugal}

After the 1755 Lisbon earthquake, Portugal published what is believed to be one of the first seismic building code ever developed (Borges, 1960), but it took two centuries until the publication of its next and first official code. Traditional stone masonry is still seen at many places in the country, but the technique was only briefly mentioned in the 1951 General Regulation for Urban Buildings (RGEU, 1951). It described some basic dimensions for both cut, as well as irregular stone walls, and allowed masonry buildings up to 7 floors. It also mentioned that provisions should be made in earthquake zones, but these specifications were not published until the first official seismic code of 1958 (RSCCS, 1958), which divided Portugal's mainland into three seismic zones. It described that buildings with "strong masonry walls" and higher than 3 floors in the most severe zone A (and 4 floors in zone B), must be reinforced with concrete tie-beams, in which case seismic verification is not necessary. No further codes nor provisions were developed for masonry in general until the adoption of Eurocode, which rules out rubble stone.

\section{Spain}

In Spain, stone masonry has been used abundantly in the past, such as in the seismically active region of Andalucía. The preliminary Spanish seismic code PGS-1 (1968) only permitted Ashlar units for stone masonry, with the inclusion of certain earthquake-resistant features. The first official code PDS-1 (1974) had added dry-stacked rubble stone, as well as roughly cut Ashlar, but without mention of rubble stone masonry with mortar. Since 1994 stone masonry is no longer clearly specified in the seismic code (NCSE-94, 1995) nor the masonry code (NBE-FL-90, 1991), other than one specific restriction for dry-stacked stone masonry. Also, the Spanish National Annexes mention nothing different than is described in the Eurocodes.

\section{Italy}

In Italy, the mention of stone masonry in either Regional Regulations (RE/RD/RDL), Governmental Decrees (DM) and Technical Norms (NTC) goes back to the nineteenth century. After the 1883 Casamicciola earthquake, only single-story masonry buildings with light roofs were allowed in this region, either with ordinary bricks or tuff stones grinded into a parallelepiped shape (RE-09/01/n.212, 1884). This was revised in 1909 to single-story buildings with shaped or "properly broken" rubble stones and river boulders, with a maximum wall spacing of $5 \mathrm{~m}$, and reinforced either with concrete bands or with closely spaced horizontal courses of bricks at height intervals of $60 \mathrm{~cm}$ (RD-18/04/n.193, 1909). The latter masonry type is called "muratura a pietrame listata" or simply "muratura listata," which is still included in today's code. Already since these earliest codes, the use of mud mortar was, and still is, strictly forbidden. In 1935 two seismic zones were introduced (RDL22/03/n.640, 1935). The more severe zone 1 allowed muratura listata of two stories height with cross-walls at maximum spacing of $6 \mathrm{~m}$, and zone 2 allowed three stories with maximum $12 \mathrm{~m}$ height and $7 \mathrm{~m}$ cross-wall spacing. The wall thickness of the ground floor ranged from 40 and $75 \mathrm{~cm}$, depending on the seismic zone and the number of floors above. The maximum number of stories for muratura listata was reduced with one floor for each seismic category in 1962 (L-25/11/n.1684, 1962) and a continuous reinforced concrete band was added at all floor levels. In 1987 Italy introduced its first official masonry code (DM-20/11, 1987) with a separate chapter for stone masonry. These rules are still largely incorporated in the latest seismic code NTC-2018 (2018), which only allows "simple" stone masonry buildings in the lowest seismic zones $\left(\mathrm{ag}_{\mathrm{g}} \cdot \mathrm{S} \leq 0.075 \mathrm{~g}\right)$. Here, three-story buildings are allowed with maximum wall spacing of $7 \mathrm{~m}$ and minimum wall thicknesses of $400 \mathrm{~mm}$ for muratura listata and $500 \mathrm{~mm}$ for coarsely worked quarry stones; provided that the stones conform to certain mechanical characteristics for strength, compression and durability. Wooden floors and roofs are not specifically mentioned but are commonly used in Italian stone buildings in Italy. The horizontal rows of bricks can be replaced with continuous reinforced or unreinforced concrete bands. Although restricted to areas with a low seismic hazard, with these clauses the Italian national codes deviate from Eurocode.

\section{OVERVIEW OF NATIONAL SEISMIC AND MASONRY CODES}

This chapter summarizes the design specifications for those countries that still allow the technique of rubble stone masonry buildings with cement mortar and wooden diaphragms in seismic areas. It further highlights some overall observations of the national seismic and masonry codes that may need attention, for which suggestions and recommendations for improvement are given.

\section{Summary of Design Specifications}

Currently, the application of nominally reinforced rubble stone masonry (NRM) with cement mortar and wooden diaphragms in seismic areas, is only mentioned in the national codes of 15 countries in the world. However, 8 countries need to be excluded from further review for various reasons. In Turkmenistan and Uzbekistan, the technique is allowed, but only briefly mentioned without any further detail. In the countries that still use the former Yugoslavian code (Bosnia-Herzegovina, Montenegro, Kosovo and North Macedonia), the technique is "not clearly ruled out" and rubble stone is (possibly) classified under "other 
materials." But since these former Balkan countries are in the process of adopting Eurocode, this will likely result in the rejection of rubble stone masonry in this region. Armenia must be excluded, because wooden diaphragms are prohibited, and their main construction material is dimensioned tuff stone blocks; rubble stone masonry is not commonly used. And lastly Italy, where rubble stone is still allowed, but only in zones with a very low seismic risk. This leaves 7 countries where the use of rubble stone masonry for buildings in highly seismic areas is still practiced and specifically allowed, for which the main requirements and design specifications are summarized in Table 1. These are Nepal, India, China, Georgia, Iran and Croatia. In Tajikistan the technique is not ruled out as it is only "recommended" to use cut stones, and is therefore added to the list; also because this is in line with the current needs and practices in the country.

Overall, it is observed that the allowed dimensions of building volumes and their individual elements vary greatly between the countries. Maximum building lengths between seismic gaps range from a ratio of $\mathrm{L}=2 \mathrm{~W}$ (or $25 \mathrm{~m}$ ) in Iran to $80 \mathrm{~m}$ length in Georgia. The maximum number of stories ranges from just one in Iran and China to five in Croatia, which is a remarkable difference as each corresponding maximum acceleration at site is $0.20 \mathrm{~g}$. There is also no agreement on the dimensions of openings (between 25 and $50 \%$ of wall length), minimum lengths of corner masonry (between 230 and 1,800 $\mathrm{mm}$ ) and piers (between 450 and 1,550 $\mathrm{mm}$ ), as well as methods and numbers of nominal reinforcements. Nepal requires concrete horizontal reinforcements at six levels (four beams or bands and stitches at two levels), China requires two beams and three to four rows of steel rod stitches (depending on story height), India only requires two beams when building on rock soil. All other codes require just one horizontal tie-beam at floor or roof level, with additional rows of bricks in Georgia. Inclusion of vertical reinforcements at critical connections is only required in India and Nepal.

TABLE 1 | Main design requirements according to seven national seismic codes that currently allow nominally reinforced rubble stone masonry in seismic areas.

\begin{tabular}{|c|c|c|c|c|c|c|c|}
\hline $\begin{array}{l}\text { Code requirements for houses and } \\
\text { schools in rubble stone masonry }\end{array}$ & $\begin{array}{c}\text { NBC } \\
202: 2015 \\
(2015)\end{array}$ & $\begin{array}{c}\text { IS:13828-1993 } \\
\text { (2008) }\end{array}$ & $\begin{array}{c}\text { JGJ } \\
161-2008 \\
(2008)\end{array}$ & $\begin{array}{c}\text { MKS CT } \\
22-07-2007 \\
(2007)\end{array}$ & $\begin{array}{l}\text { PN 01.01-09 } \\
\quad(2010)\end{array}$ & $\begin{array}{c}\text { NBRI-8 } \\
\text { (2013) }\end{array}$ & $\begin{array}{c}\text { nHRN EN } \\
1998-1: 2011 / N A \\
(2011)\end{array}$ \\
\hline \multicolumn{8}{|l|}{ General } \\
\hline Country & Nepal & India & China & Tajikistan & Georgia & Iran & Croatia \\
\hline Seismic zones (low to high) & $1-4$ & $\|-V$ & 6-9 pt. & 7-9 pt. & 7-9 pt. & $1-4$ & mapped \\
\hline Houses $(H)$ or Schools $(\mathrm{S})$ & $\mathrm{H}, \mathrm{S}^{\mathrm{a}}$ & $H\left(S^{C}\right)$ & $\mathrm{H}$ & $\mathrm{H}, \mathrm{S}$ & $\mathrm{H}, \mathrm{S}$ & $H, S$ & $H, S^{*}$ \\
\hline Max. allowed seismic zone & - & III (IVd) & 7 & 9 & $? 8$ or 9 & 1 & - \\
\hline Max. allowed acceleration & $-(0.40 \mathrm{~g})^{\mathrm{b}}$ & $0.08 g\left(0.12 g^{d}\right)$ & $0.15 \mathrm{~g}$ & $0.40 \mathrm{~g}$ & $? 0.24 \mathrm{~g}$ or $0.52 \mathrm{~g}$ & $0.20 \mathrm{~g}$ & $>0.30 g^{\star}\left(0.20 g^{\ominus}\right)$ \\
\hline Wooden floor/roof allowed & Yes & Yes & Yes & Yes & Yes & Yes & * \\
\hline \multicolumn{8}{|l|}{ Volumes and dimensions (in m) } \\
\hline Max. ratio length $(L)$ versus width $(W)$ & $L=3 W$ & - & - & - & - & $L=2 W$ & $\mathrm{~L}=4 \mathrm{~W}$ \\
\hline Max. length btw seismic gaps & - & - & - & 45 & 80 & 25 & - \\
\hline Max. number of stories & $2+$ attic & $2+$ attic & 1 sto. & 2 sto. & ? 2 or 1 & 1 sto. & 5 or 2 st. $^{f}$ \\
\hline Max. height of building & - & - & 3.6 & 8.0 & - & 3.5 & - \\
\hline Max. unsupported wall length & 4.5 & 5.0 & 11.0 & 9.0 & 6.0 & 4.0 & 7.0 \\
\hline Max. height floor-to-floor & 3.0 & 3.0 & 3.5 & 4.5 & $4.0(\mathrm{H})$ & - & $(h / t)<9$ \\
\hline Mortar ratio cement-lime-sand & $1: 6 \mathrm{c}-\mathrm{s}$ & $1: 6 \mathrm{c}-\mathrm{s}$ & $>1 \mathrm{MPa}$ & $>5 \mathrm{MPa}$ & M2.5/M59 & $1: 3 / 1: 1: 6$ & $>5 \mathrm{MPa}$ \\
\hline Max. spacing buttresses (if req.) & 3.0 & 4.0 & - & - & - & - & - \\
\hline \multicolumn{8}{|l|}{ Walls and openings (in $\mathrm{mm}$ ) } \\
\hline Min. wall thickness & 350 & 350 & 400 & - & - & 450 & 450 \\
\hline Max. wall thickness & - & 450 & - & - & - & - & - \\
\hline Max. \% openings in wall (1 sto.) & $30 \%$ & $46 \%$ & $50 \%{ }^{h}$ & $25 \%$ & - & $50 \%$ & $\%$ Afloor \\
\hline Max.\% openings in wall (2 sto.) & $30 \%$ & $37 \%$ & - & $25 \%$ & - & - & $\%$ Afloor \\
\hline Max. length of openings & - & - & $1,800^{h}$ & 2,500 & - & 1,200 & $\%$ Afloor \\
\hline Min. distance corner to door & 600 & 230 & 1,000 & 1,800 & - & 2/3 h (d) & $(\mathrm{l} / \mathrm{h})>0.5$ \\
\hline Min. distance corner to window & 600 & 230 & 1,000 & 1,800 & - & $2 / 3 \mathrm{~h}(\mathrm{w})$ & $(1 / h)>0.5$ \\
\hline Min. size piers between openings & 600 & 450 & 1,000 & 1,550 & - & 650 & $(\mathrm{l} / \mathrm{h})>0.5$ \\
\hline \multicolumn{8}{|l|}{ Nominal reinforcements } \\
\hline Horizontal concrete bands per story & $\min .4$ & $\min .2$ & 2 & 1 & 1 & 1 & 1 \\
\hline Stitches(s), mesh(m), brick bands (bb) & $\min .2 \mathrm{~s}$ & - & $\min .3 \mathrm{~s}$ & $\mathrm{~m}$ & $\mathrm{bb}$ & - & - \\
\hline Vertical bars (b) or columns (c) & $b$ & $b$ & - & n.mand. & - & - & - \\
\hline
\end{tabular}

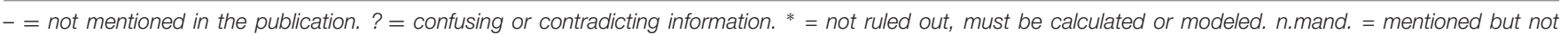

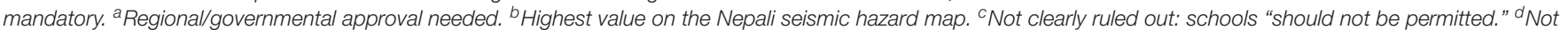

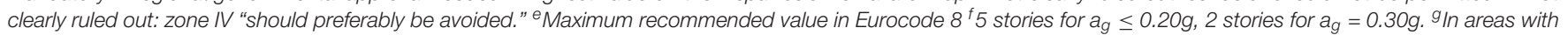
temperatures below $0^{\circ} \mathrm{C} .{ }^{h} / \mathrm{n}$ longitudinal walls; in cross-walls this is $25 \%$ and $1,500 \mathrm{~mm}$. 
Most striking, however, are the huge differences between maximum allowed design accelerations, ranging from just $0.08 \mathrm{~g}$ in Indian zone III versus $0.52 \mathrm{~g}$ on medium soils in Georgia. Moreover, it is observed that some countries are not taking the implications of different seismic hazard levels into account. For instance, the current design rules in Nepal are the same for all seismic levels, which may result in either excessively reinforced buildings in low seismic zones, or worse, in insufficiently reinforced buildings in highly seismic areas. These huge differences between basically all design requirements are raising questions about the completeness and correctness, as well as the reliability and actual value of the knowledge in this field. The same was concluded after the literature review of practical manuals (the first paper in this series), where the currently available information was perceived as highly confusing, contradicting and incomplete (Schildkamp and Araki, 2019a).

\section{Observations and Recommendations}

The review of national seismic and masonry codes has brought several further issues to light. Firstly, it is seldom clearly described what type of masonry construction is addressed. It is therefore proposed to internationally adopt loadbearing Nominally Reinforced Masonry (NRM) as a fourth category. The main reason is to make a clear distinction between NRM and "truly" URM, next to RM and CM. It is also important that codes clearly mention what stone types are allowed, with a clear difference between random rubble, and cut stones with brick-like dimensions. This is particularly the case for all Russian-based codes in Central Asia and the Caucasus, which indirectly refer to clauses that were developed in the 1950s for dimensioned tuff stones. During the many revisions that followed, the stone properties are no longer specifically mentioned and therefore leaves room for interpretation. Such as the Uzbek code KMK 2.01.03-96 (2004) which has copied clauses for regular shaped stones from the Russian seismic code of 1981 (SNiP II-7-81*, 1989). However, it is generally assumed that these relate to rubble stones, since this is the most generally used construction material, whereas dimensioned tuffs were never common at all in Uzbekistan (Nurtaev, 2019). The Indian seismic code IS:1893 (part 1)-2016 (2016) also leaves room for interpretation as stone masonry "should preferably be avoided" in seismic zone IV, and construction of schools "should not be permitted." The overall point is: Any possible misinterpretation can easily be avoided by adding a clear line in the codes, which specifically states whether rubble stone masonry is allowed or not; and to what type of buildings and structures it applies.

Secondly, it is praiseworthy that a few countries have developed separate codes for "non-engineered" construction types, such as the Indian code IS:13828-1993 (2008). Unfortunately, this code has become very difficult to read and interpret, due to its many amendments and references to other codes outside the publication, such as for foundations, stone types and seismic provisions. Some data had to be found in a footnote which referred to another footnote. Also, it is questionable whether sizes, dimensions and details for thinner brick walls can be freely interchanged with those for thicker rubble stone walls, as also observed in the Nepalese "nonengineered” codes (NBC 202:2015, 2015). Such interchanging of incompatible information may also be the case in the seismic code of Georgia (PN 01.01-09, 2012), where the very generous design specifications are presumably meant for brick masonry, rather than for rubble stone buildings. To enhance clarity and avoid further confusion, the proposed solution is to develop a stand-alone code that is specifically intended for NRM rubble stone buildings in cement mortar. Block and brick masonry behave differently than stone masonry, and a clear distinction must be made between different types of mortars, such as cement or mud. It is further recommended to structure the national codes for non-engineered techniques in such a way, that all the necessary information is compiled in just one document, with step-by-step explanations of the various procedures of design and execution of the technique.

Lastly, it is important to note that a significant number of countries where stone masonry is still broadly practiced today, are currently not allowing the technique, or have no codes in place to begin with, such as Afghanistan, Pakistan, Bhutan, Azerbaijan, Kyrgyzstan, Morocco, Tunisia, Turkey, Yemen, and Albania. For instance, in Afghanistan most of the construction takes place in rural areas and with traditional techniques. However, the Afghan building code ABC-2012 (2012) is a collection of USbased clauses that are not in line with the current engineering practices and construction needs in the country (Mashal and Sarwary, 2018). Similarly, the US-based Pakistani code (BCP-SP07, 2007), as well as the Indian seismic code which effectively prohibits stone masonry in the whole Himalayan region (seismic zones IV and V), do not properly reflect the current needs in their respective countries.

\section{CONCLUSION}

Nearly 325 national seismic and masonry codes from all over the world, divided over 5 different continents, have been analyzed and compared. The current state-of-the-art for new rubble stone masonry buildings in seismic areas was reviewed for 57 countries in total, of which 31 in more detail. The following is concluded:

- Currently, the technique of nominally reinforced rubble stone masonry buildings with cement mortar and wooden diaphragms in seismic areas, is only allowed in seven countries in the world; Nepal, India, China, Tajikistan, Georgia, Iran and Croatia.

- No consensus was found on any of the design specifications and main dimensions between these countries and the differences vary greatly, which raises questions about the reliability and value of the knowledge in this field.

- The definition of the loadbearing masonry type "URM" may be perceived as misleading in earthquake engineering, as truly URM is not allowed in any of the codes. It is therefore proposed to internationally adopt "NRM," which stands for Nominally Reinforced Masonry, as an additional masonry category. 
- The permitted use of rubble stone masonry, as well as the specifications for stone units are seldom clearly described in the codes. This can easily be improved by adding a line in the codes, which specifically states whether the technique is allowed or not.

- A further recommendation is to develop a stand-alone code for rubble stone masonry buildings, to avoid misinterpretation and interchange of incompatible design specifications that are meant for other techniques.

- Several countries where rubble stone masonry is still abundantly practiced, completely rule out the technique in their codes or have no codes in place. This is not in line with the current needs in these countries, such as in Afghanistan, Pakistan, Bhutan, Azerbaijan, Kyrgyzstan, Morocco, Tunisia, Turkey, Yemen and Albania.

To address all these above-mentioned shortcomings, the authors of this paper propose a full assessment, validation, optimization and complementation of the existing knowledge, by means of the current state-of-the-art for calculating, testing and modeling. To achieve this, a research initiative is started by the name of SMARTnet, which stands for Seismic Methodologies for Applied Research and Testing of non-engineered Techniques. The philosophy includes an updated and structured research approach that specifically addresses vernacular and traditional construction techniques: "Non-Engineered 2.0." This third paper is a valuable addition to collect, review and compare the design specifications for rubble stone masonry buildings worldwide. These specifications as summarized in Table 1 will serve as the starting point for the upcoming paper, which will complement the seismic demand with hand-made base shear calculations for countries that still (or should) allow the technique. This seismic demand then needs to be validated by the seismic capacity of the structures, for which the key lies in the determination of reliable material properties that reflect local materials and workmanship. It is realized that the challenge is huge and the scope of work enormous, for which help is needed. The strategy of SMARTnet envisions a joint approach of global collaboration, to cope with the massive number of material variables, as well as to generate cross-checked data that can be used for calculations and computer modeling of non-engineered techniques.

SMARTnet invites experts, professionals, academics as well as final-year students in these fields to exchange their knowledge and to support the project with their time and expertise. Fact is that millions of people will continue to live in stone houses in India, Nepal, Pakistan, Bhutan, Afghanistan, China, and likely in regions in Central Asia, the Middle East, Northern Africa and Europe as well. They need clear and reliable information that is up-to-date and complete. It is expected that a full validation and justification of the seismic behavior of rubble stone masonry

\section{REFERENCES}

08SG618-4 (2008). National Architectural Atlas - Detailed Seismic Structure of Rural Stone Structured Houses (in Chinese). Wuhan: China Institute of Building Standard Design \& Research.

1982-102-1 (1982). Seismic Resistant Structures - Design Standards and Criteria (in Persian). Kabul: Urban and Construction Projects Institute. buildings will strengthen the confidence in those countries that still use this technique, as well as creates renewed interest in countries that currently prohibit it.

\section{AUTHOR CONTRIBUTIONS}

MS collected all data, coordinated all fact-checking through interaction with the experts worldwide, and wrote the manuscript. YA and SS assisted in collection of data and reviewed, revised, and restructured the manuscript. All authors contributed to the article and approved the submitted version.

\section{FUNDING}

This work was supported by the Grant-in-Aid for Scientific Research (KAKENHI) of Japan Society for the Promotion of Science (JSPS) under grant number (B) 17H04592, as well as by the Dutch organization ArchiScienza, Fund for Architecture and Science, and the Dutch organization Prins Bernhard Cultuurfonds. Their support is greatly appreciated.

\section{ACKNOWLEDGMENTS}

We wish to acknowledge everyone who has assisted with our search for the national seismic, masonry and building codes, and in particular C. Bodnar-Anderson, librarian of the NISEE-PEER Library. We are immensely grateful to the following persons for their invaluable feedback on translations, interpretations, and fact-checking of their respective countries' codes: Assist. Prof. K. Shrestha and MEng. J. Bothara (Nepal), Prof. Y. Singh and Assist. Prof. M. Raghunandan (India), Prof. S. Lodi, Assist. Prof. N. Ahmad and S. Qazi (Pakistan), MEng. N. Aloko (Afghanistan), Dr. G. Ho, MEng. C. Zhong, and Assist. Prof. J. Guo (China), Assoc. Prof. T. Miller (US-based codes), Y. Vorfolomeyeva (all Russian-based codes), Dr. J. Nizomov (Tajikistan), Assoc. Prof. S. Imanbekov (Kyrgyzstan), Prof. T. Dadayan and MEng. K. Vardanyan (Armenia), Prof. A. Alifov (Azerbaijan), Assist. Prof. I. Salukvadze (Georgia), Dr. A. Naderzadeh (Iran), Prof. P. Gülkan and MEng. O. Türkcan (Turkey), Prof. D. Benouar and Prof. A. Bourzam (Northern Africa, Algeria), Dr. Y. Mahgoub and Dr. S. Raheem (Egypt), Prof. N. Armouti (Jordan and Syria), Dr. M. Al-Shuwaili (Iraq), Dr. O. Kegyes-Brassai (Romania), MEng. M. Pantusheva (Bulgaria), Assist. Prof. M. Novak and Prof. Hadzima-Nyarko (former Yugoslavian codes, Croatia), Dr. E. Mustafaraj and Prof. H. Bilgin (Albania), MArch. D. Kouinoglou (Greece), Assoc. Prof. R. Bento (Portugal), and MEng. A. Marchena (Spain).

1983-7-II (1983). Norms for Planning and Design of Structures in Seismic Areas (in Persian). Kabul: Urban and Construction Projects Institute.

ABC-2012 (2012). Afghanistan Building Code 2012, Afghan Structural Code (ASC). Kabul: Government of Islamic Republic of Afghanistan.

ABYYHY-68 (1968). Regulation for Structures in Disaster Areas. Resmî Gazete n.12801 of 16/01/1968 (in Turkish). Ankara: Ministry of Public Works and Settlement. 
ABYYHY-75 (1975). Regulation for Structures in Disaster Areas. Resmî Gazete n.15260 of 09/06/1975 (in Turkish). Ankara: Ministry of Public Works and Housing.

ACI 530/530.1-11 (2011). Building Code Requirements and Specification for Masonry Structures: Containing Building Code Requirements for Masonry Structures (TMS 402-11/ACI 530-11/ASCE 5-11), and Specification for Masonry Structures TMS 402-11/ACI 530.1-11/ASCE 6-11), and Companion Commentaries. Boulder, CO: The Masonry Society.

Ahmadizadeh, M., and Shakib, H. (2016). Experimental study of the in-plane behavior of confined stone masonry walls. J. Struct. Eng. 142:04015145. doi: 10.1061/(asce)st.1943-541x.0001417

Al-Nimry, H., Armouti, N., and Najmi, A. (2003). "Inelastic cyclic response of stone-concrete bearing walls," in Proceedings of the 6th International Conference on Concrete Technology for Developing Countries, (Amman: Musa Resheidat).

Applied Technology Council (2017). Guidelines for Seismic Reconstruction of School Buildings and Design of New School Buildings in the Republic of Armenia (in Armenian). Yerevan: Government of the Republic of Armenia.

Arya, A. S. (1977). "Codes," in Proceedings of the 6th World Conference on Earthquake Engineering, (New Delhi: Indian Society of Earthquake Technology).

Arya, A. S. (2000). "Non-engineering construction in developing countries-an approach toward earthquake risk reduction," in Proceedings of the 12th World Conference on Earthquake Engineering (Auckland), (Upper Hutt: New Zealand Society for Earthquake Engineering).

AS55 (1955). Recommendations for Constructions to be Built in Regions Subject to Earthquakes (in French). Algiers: Ministry of Housing and Reconstruction.

ASCE/SEI 7-10 (2010). Minimum Design Loads for Buildings and Other Structures. Reston, VA: American Society of Civil Engineers.

ASTM C568/C568M (2015). Standard Specification for Limestone Dimension Stone. West Conshohocken, PA: ASTM International.

ASTM C615/C615M (2018). Standard Specification for Granite Dimension Stone. West Conshohocken, PA: ASTM International.

ASTM C616/C616M (2015). Standard Specification for Quartz-Based Dimension Stone. West Conshohocken, PA: ASTM International.

Athanasopoulou, A., Formichi, P., Spehl, P., Dabizheva, I., Gacesa-Moric, V., and Markova, J. (2019). EUR 29601 EN - The Implementation of the Eurocodes in the National Regulatory Framework. Luxembourg: Publications Office of the European Union.

Aydan, Ö, Ulusay, R., Kumsar, H., and Konagai, K. (2012). Site Investigation and Engineering Evaluation of the Van Earthquakes of October 23 and November 9, 2011. Tokyo: Japan Society of Civil Engineers.

AzDTN 2.3-1 (2014). Construction in Seismic Areas (in Azerbaijani). With amendments D1 (2011) and D2 (2014). Baku: Committee for Architecture and Urban Planning of the Republic of Azerbaijan.

BCP-86 (1986). Building Code of Pakistan. Islamabad: Government of Pakistan.

BCP-SP-07 (2007). Building Code of Pakistan (Seismic Provisions - 2007). Islamabad: Government of Islamic Republic of Pakistan.

BD-19/02 (1959). On Earthquake Resistant Regulation of Construction Works (in Greek). Government Gazette n.36 of February 26, 1956, Athens.

BNBC-2017 (2017). Bangladesh National Building Code 2017, Volume 1 and 2. Dhaka: Housing and Building Research Institute.

Borges, F. (1960). "Portuguese studies on earthquake resistant structures," in Proceedings of the 2nd World Conference on Earthquake Engineering, (Tokyo: Gakujutsu Bunken Fukuy-Rai).

C193-79 (1979). Technical Instructions for the Execution of Rubble Stone Masonry (in Romanian). Bucharest: Central Research Institute for Design and Management in Construction.

Carabbio, R., Pieraccini, L., Silvestri, S., and Schildkamp, M. (2018). How can vernacular construction techniques sustain earthquakes: the case of the bhatar buildings. Front. Built Environ 4:18. doi: 10.3389/fbuil.2018. 00018

CECS 317:2012 (2012). Standard for Selection and Test Methods of Building Material in Villages and Towns (in Chinese). Beijing: China Association for Engineering Construction Standardization.

Cherkaoui, T., and El Hassani, A. (2012). Seismicity and Seismic Hazard in Morocco 1901-2010. Rabat: Bulletin de l'Institut Scientifique, section Sciences de la Terre, n.34. 45-55.
Chesneau, M. (1892). Notes sur les Tremblements de Terre en Algérie, Vol. 1. Paris: Annales des Mines, 5-46.

Construction Standard 109 (2008). Standard for Construction of Primary and Secondary Schools in Rural Areas (in Chinese). Beijing: Ministry of Housing and Urban-Rural Development of the People's Republic of China.

CSCR-2010 (2014). Seismic Code of Costa Rica, Revision 2014 (in Spanish). San Jose: College Federation of Engineers and Architects of Costa Rica.

DBYBHY (2007). Regulation on Buildings in Seismic Zones. Resmî Gazete n.26454 of 06/03/2007 (in Turkish). Ankara: Ministry of Public Works and Settlement.

Decree 372-30.5.2014 (2014). Approval of the Application and Use of the Eurocodes in Combination with the Respective National Appendices (in Greek). Government Gazette n.1457 of June 5, 2014, Athens.

Decree n.15 (1947). Regulations for Design of Buildings and Engineering Structures in the Seismic Regions of Bulgaria (in Bulgarian). State Journal n.98 of 30 April, 1947, Sofia.

DM-20/11 (1987). Technical Regulations for the Design, Execution and Testing of Masonry Buildings and for their Consolidation (in Italian). Gazzetta Ufficiale n.285 del 5 Dicembre 1987, Rome.

DTU Règles-PS-69 (1970). Earthquake Resistant Construction Rules 1969 and Annexes (in French). Paris: Société de Diffusion des Techniques du Bâtiment et des Travaux Publics.

DTU Règles-PS-92 (2004). DTU NF P06-013 - Earthquake Resistant Construction Rules Applicable to Buildings, called PS 92 (in French). Paris: Association Française de Normalisation.

E.080 (2017). Design and Construction with Reinforced Earth, Annex - Decree n.121-2017-VIVIENDA from the Ministry of Housing, Construction and Sanitation (in Spanish). Diario Oficial del Bicentenario 7 de abril de 2017, Lima. E.100 (2012). Technical Norms - Bamboo (in Spanish). Lima: Ministry of Housing. EAK2000 (2010). Greek code for Seismic Resistant Structures - EAK2000, with Amendments (in Greek). Athens: Organisation for Earthquake Resistant Planning and Protection.

ECP-204 (2005). Egyptian Code for the Design and Implementation of Building Works (in Arabic). Cairo: Housing and Building National Research Center.

EN 1996-1-1 (2005). Eurocode 6 - Design of Masonry Structures - Part 1-1: General Rules for Reinforced and Unreinforced Masonry Structures. Brussels: European Committee for Standardization.

EN 1998-1:2004+A1 (2013). Eurocode 8: Design of Structures for Earthquake Resistance - Part 1: General Rules, Seismic Actions and Rules for Buildings, Incorporating Corrigendum July 2009. Brussels: European Committee for Standardization.

EN 771-6:2011+A1 (2015). Specification for Masonry Units - Part 6: Natural Stone Masonry Units. Brussels: European Committee for Standardization.

G.P.(Q)23-3,100-10-77 (1976). Quetta Development Authority Building Rules, 1976. Quetta: Quetta Development Authority.

GB 50011-2010 (2016). Code for Seismic Design of Buildings, 2016 Edition (in Chinese). Beijing: Ministry of Housing and Urban-Rural Development of the People's Republic of China.

GB 50099-2011 (2010). Code for Design of Schools. Design Specifications for Primary and Secondary Schools (in Chinese). Beijing: Ministry of Housing and UrbanRural Development of the People's Republic of China.

GB/T 33735-2017 (2017). Guideline of Avoiding the Earthquake Danger for Primary and Middle Schools (in Chinese). Beijing: Standardization Administration of China, jointly with General Administration of Quality Supervision.

GBJ 11-89 (1993). Code for Seismic Design of Buildings, Revised Version (in Chinese). Beijing: Ministry of Construction of the People's Republic of China.

GOST 4001-2013 (2014). Wall Stones from Rocks - Technical Specifications (in Russian). Minsk: Interstate Council for Standardization.

GOST 4001-66 (1967). Limestone and Tuff Wall Blocks (in Russian). Moscow: State Committee of the Council of Ministers of the USSR for Construction.

Hicyilmaz, K. (2011). Dhajji Dewari, Affordable Seismically Resistant and Sustainable Housing, Revision C. Dubai: Arup Gulf Ltd.

HRN EN 1996-1-1:2012/NA (2012). Eurocode 6 - Design of Masonry Structures Part 1-1: General Rules for Reinforced and Unreinforced Masonry Structures National Annex (in Croatian). Zagreb: Croatian Standards Institute.

IBC-2009 (2009). 2009 International Building Code. Country Club Hills, IL: International Code Council. 
IS:13828-1993 (1993). Improving Earthquake Resistance of Low Strength Masonry Buildings-Guidelines. New Delhi: Bureau of Indian Standards.

IS:13828-1993 (2018). Improving Earthquake Resistance of Low Strength Masonry Buildings. Guidelines, 3rd Reprint 2008 incl. Amendments nos 1. 2 \& 3, Reaffirmed 2018. New Delhi: Bureau of Indian Standards.

IS 1893 (part 1)-2002 (2002). Criteria for Earthquake Resistant Design of Structures. Part 1 General Provisions and Buildings (Fifth Revision). New Delhi: Bureau of Indian Standards.

IS:1893 (part 1)-2016 (2016). Criteria for Earthquake Resistant Design of Structures. Part 1 General Provisions and Buildings (Sixth Revision). New Delhi: Bureau of Indian Standards.

IS:4326-1993 (1993). Earthquake Resistant Design and Construction of Buildings Code of Practice (Second Revision). New Delhi: Bureau of Indian Standards.

IS:SP7-2016 (2016). National Building Code of India 2016, Vol. 1. New Delhi: Bureau of Indian Standards.

IS:1597 (part 1)-1967 (1967). Code of Practice for Construction of Stone Masonry, Part 1 Rubble Stone Masonry. New Delhi: Indian Standards Institution.

IS:1597(part 2)-1992 (2016). Construction of Stone Masonry - Code of Practice, Part 2 Ashlar Masonry (First Revision), 1st Reprint 1998, Reaffirmed 2018. New Delhi: Bureau of Indian Standards.

IS:1893-1962 (1962). Recommendations for Earthquake Resistant Design of Structures. New Delhi: Indian Standards Institution.

IS:1893-1970 (1970). Criteria for Earthquake Resistant Design of Structures (Second Revision). New Delhi: Indian Standards Institution.

IS:1905-1961 (1962). Code of Practice for Structural Safety of Buildings: Masonry Walls. New Delhi: Indian Standards Institution.

IS:1905-1987 (1989). Code of Practice for Structural Use of Unreinforced Masonry (Third Revision). New Delhi: Bureau of Indian Standards.

IS:1905-1987 (2017). Code of Practice for Structural Use of Unreinforced Masonry (Third Revision), 1st Reprint 1995, Reaffirmed 2017. New Delhi: Bureau of Indian Standards.

IS:4326-1967 (1968). Code of Practice for Earthquake Resistant Construction of Buildings. New Delhi: Indian Standards Institution.

IS:4326-1976 (1977). Code of Practice for Earthquake Resistant Design and Construction of Buildings (First Revision). New Delhi: Indian Standards Institution.

ISC-303 (2017). Iraqi Seismic Code 303 (in Arabic). Baghdad: Ministry of Construction and Housing.

Jade, S., Shrungeshwara, T., Kumar, K., Choudhury, P., Dumka, R., and Bhu, H. (2017). India plate angular velocity and contemporary deformation rates from continuous GPS measurements from 1996 to 2015. Sci. Rep. 7:11439. doi: 10.1038/s41598-017-11697-w

JGJ 161-2008 (2008). Seismic Technical Specification for Building Construction in Town and Village (in Chinese). Beijing: Ministry of Housing and Urban-Rural Development of the People's Republic of China.

Kaufmann, C., Langhammer, T., Schwarz, J., Khakimov, S., and Tulaganov, B. (2004). "Evaluation and strengthening of public buildings after the Kamashi (Uzbekistan) earthquakes in 2000 and 2001," in Proceedings of the 13th World Conference on Earthquake Engineering, (Vancouver, BC: 13 WCEE Secretariat).

KMK 2.01.03-96 (2004). Construction in Seismic Areas. With Amendment No.1 (in Russian). Tashkent: Committee of the Republic of Uzbekistan on Architecture and Construction.

KTP-2-78 (1978). Technical Design Conditions Book 1 - Technical Design Conditions for Constructions in Seismic Zones (in Albanian). Tirana: Mihal Duri Printing House.

KTP-N.2-89 (1989). Technical Regulations for Earthquake Resistant Design (in Albanian). Tirana: Academy of Sciences.

L-25/11/n.1684 (1962). Provisions for the Building Industry, with Special Requirements for Seismic Zones (in Italian). Gazzetta Ufficiale n.324 del 22 Dicembre 1962, Rome.

Lodi, S. H. (2015). 10 Years After the 2005 Earthquake: Lessons Learned and Opportunities for Risk Reduction in Pakistan-Earthquake and Vulnerability of Pakistan and Risk Scenarios. Powerpoint Presentation.

Mashal, M., and Sarwary, I. (2018). Current practice of earthquake engineering in construction industry in Afghanistan and recommendations. MOJ Civil Eng. 4, 60-64. doi: 10.15406/mojce.2018.04.00098
Medvedev, S., and Sponheuer, W. (1969). "Scale of seismic intensity," in Proceedings of the 4th World Conference on Earthquake Engineering, (Santiago: Universidad de Chile).

MKS CT 22-07-2007 (2007). Earthquake-Resistant Construction. Design Standards (in Tajik and Russian). Dushanbe: Agency for Construction and Architecture under the Government of the Republic of Tajikistan.

Moinfar, A., Naderzadeh, A., and Nabavi, M. (2012). "New Iranian seismic hazard zoning map for new edition of seismic code and its comparison with neighbor countries," in Proceedings of the 15th World Conference on Earthquake Engineering, (Lisboa: Curran Associates, Inc).

MUDH (2003). Guidelines for Earthquake Resistant Design, Construction and Retrofitting of Buildings in Afghanistan. Kobe: Ministry of Urban Development and Housing.

National Planning Commission (2015). Post Disaster Needs Assessment (PDNA). Vol. B: Sector Reports. Kathmandu: Government of Nepal.

NBC 105:1994 (2007). Seismic Design of Buildings in Nepal, V2.RV5, reprint. Kathmandu: Department of Urban Development and Building Construction.

NBC 105:2019 (2019). Seismic Design of Buildings in Nepal (draft version). Kathmandu: Department of Urban Development and Building Construction.

NBC 109:1994 (2007). Masonry: Unreinforced, Reprint. Kathmandu: Department of Urban Development and Building Construction.

NBC 202:1994 (2007). Mandatory Rules of Thumb Load Bearing Masonry, V2.RV7, reprint. Kathmandu: Department of Urban Development and Building Construction.

NBC 202:2015 (2015). Guidelines On: Load Bearing Masonry. Kathmandu: Department of Urban Development and Building Construction.

NBC 203:1994 (2007). Guidelines for Earthquake Resistant Building Construction: Low Strength Masonry, V1.RV1, reprint. Kathmandu: Department of Urban Development and Building Construction.

NBC 203:2015 (2015). Guidelines for Earthquake Resistant Building Construction: Low Strength Masonry. Kathmandu: Department of Urban Development and Building Construction.

NBE-FL-90 (1991). Decreto 1723 - Reinforced Brick Masonry (in Spanish). Boletín Oficial del Estado n.4, January 4 of 1991, Madrid.

NBRI-8 (2013). National Building Regulations of Iran, Part 8: Design and Construction of Masonry Buildings, Second Edition (in Farsi). Tehran: Ministry of Road and Urban Development.

NCSE-94 (1995). Decreto 2543 - Earthquake Resistant Construction Standard: Part General and Building (in Spanish). Boletín Oficial del Estado n.33, February 8 of 1995, Madrid.

nHRN EN 1998-1:2011/NA (2011). Eurocode 8 - Design of Structures for Earthquake Resistance - Part 1: General Rules, Seismic Actions and Rules for Buildings - National Annex (in Croatian). Zagreb: Croatian Standards Institute.

NL-135 (2012). Protection from Earthquakes: General Rules (in English). Sin El Fil: Lebanese Standards Institution.

Normes Agadir-1960 (1960). Provisional Technical Rules Applicable to Buildings in the Disaster Area of Agadir (in French). Rabat: Ministry of Public Works.

Novikova, A., Szalay, Z., Simaku, G., Thimjo, T., Salamon, B., and Plaku, T. (2015). The Typology of the Residential Building Stock in Albania and the Modelling of its Low-Carbon Transformation. Szentendre: Regional Environmental Center for Central and Eastern Europe.

NRA (2020). Rubble Stone School Designs in Nepal After the 2015 Earthquake. Available online at: http://www.moepiu.gov.np/downloads.php?id=5 (accessed September 12, 2020)

NTC-2018 (2018). Technical Standards for Construction, Decree from the Ministry of Infrastructure and Transport of January 17, 2018 (in Italian). Gazzetta Ufficiale n.42 del 20 Febbraio 2018, Rome.

Nurtaev, B. (2019). Personal communication.

Nurtaev, B., Khakimov, S., and Miscola, A. (2017). Seismic Renovation and Reconstruction of Schools in Uzbekistan, Comprehensive School Safety Policy Case Studies Series. Paris: GADRRRES.

Ordinance RD-02-20-2 (2012). Design of Buildings and Structures in Seismic Regions (in Bulgarian). Sofia: Ministry of Regional Development and Public Works.

OSDC-2013 (2013). Seismic Design Code for Buildings, Sultanate of Oman (in English). Seeb: Sultan Qaboos University Earthquake Monitoring Center. 
Ozcebe, G., Ramirex, J., Wasti, T., and Yakut, A. (2003). 1 May 2003 Bingol Earthquake Engineering Report. Ankara: TÜBITAK jointly with NSF.

P100-1 (2013). Seismic Design Code, Part 1 - Design Provisions for Buildings (in Romanian). Bucharest: Ministry of Regional Development and Public Administration.

P100-78 (1978). Seismic Rules for the Design of Housing and Socio-Cultural, Agricultural and Industrial Buildings (in Romanian). Bucharest: Central Research Institute for Design and Management in Construction.

P13-63 (1963). Conditional Rules for the Design of Civil and Industrial Constructions in Seismic Regions (in Romanian). Bucharest: State Committee for Construction.

P2-85 (1985). Rules for Construction, Calculation and Execution of Masonry Structures (in Romanian). Bucharest: Central Research Institute for Design and Management in Construction.

PBO-64 (1964). Temporary Code to Protect Buildings Against Earthquake (in Farsi). Tehran: Plan and Budget Organization of Iran.

PDS-1 (1974). Decreto 3209 - Earthquake Resistant Standard PDS-1 (1974), Part A Indicative Standards (in Spanish). Boletín Oficial del Estado n.279, November 21 of 1974, Madrid.

PGS-1 (1968). Decreto 106 - Earthquake Resistant Standard PGS-1 (1968), Part A (in Spanish). Boletín Oficial del Estado n.30, February 4 of 1969, Madrid.

Pittore, M., and Parolai, S. (2016). Report on Residential Exposure and Seismic Vulnerability in Kyrgyzstan (Scientific Technical Report 16/03). Potsdam: GFZ German Research Center for Geosciences.

PN 01.01-09 (2012). Construction Norms and Rules - Seismic Construction. With Amendment No.1 (in Georgian). Tbilisi: Minister of Economic Development of Georgia.

PSP 101-51 (1951). Regulations on Construction in Seismic Areas (in Russian). Moscow: State Committee of the Council of Ministers of the USSR for Construction.

QBC-1937 (1937). Building Code for Quetta Municipality. Quetta: Staff College Printing Press.

RABC 20.04_(2020). Earthquake Resistant Construction. Design Codes (in Armenian). Yerevan: Ministry of Urban Development of the Republic of Armenia.

RABC II-6.02-2006 (2011). Earthquake Resistant Construction. Design Codes (in English), plus amendment N 126-N (in Armenian). Yerevan: Ministry of Urban Development of the Republic of Armenia.

RABC IV-13.01-96 (1996). Stone and Reinforced Masonry Structures (in Armenian). Yerevan: Ministry of Urban Development of the Republic of Armenia.

RD-18/04/n.193 (1909). Technical and Hygienic Standards Mandatory for Repairs, Reconstructions and New Construction of Public and Private Buildings in Places Hit by the Earthquake of December 28, 1908 (in Italian). Gazzetta Ufficiale $n .95$ del 22 Aprile 1909, Rome.

RDL n.2105 (1937). Technical Building Standards with Special Requirements for Earthquake-Affected Locations. Regio Decreto Legge n. 2105 del 22/11/1937 (in Italian). Gazzetta Ufficiale n. 298 del 27 dicembre 1937-XVI, Rome.

RDL-22/03/n.640 (1935). New Text of Technical Building Standards with Special Requirements for Earthquake-Affected Locations (in Italian). Gazzetta Ufficiale n.120 del 22 Maggio 1935, Rome.

RE-09/01/n.212 (1884). Building Regulations for the Municipalities of the Island of Ischia Damaged by the Earthquake of July 28, 1883 (in Italian). Gazzetta Ufficiale del Regno d'Italia n.212 del 1 Settembre 1884, Rome.

RGEU (1951). Decreto-Lei n.38:382 - General Regulation for Urban Buildings (in Portuguese). Diário do Governo n.166 de 7 de Agosto de 1951, Lisbon.

Royal Government of Bhutan (2014). Bhutanese Architecture Guidelines. Thimphu: Ministry of Works and Settlement.

RPA-81 (1981). Algerian Earthquake Resistant Regulations (in French). Algiers: Office des Publications Universitaires.

RPA-99 (2003). Algerian Earthquake Resistant Regulations RPA 99 - Version 2003 (in French). Algiers: Ministry of Housing and Urbanism.

RPCTerre-2011 (2013). Earthquake Resistant Rules for Buildings in Earth (in French). Bulletin Officiel n.6206 de 21 Novembre 2013, Rabat.

RPS-2000 (2011). Earthquake Resistant Construction Rules RPS 2000 - Version 2011 (in French). Rabat: Ministry of Housing and Urban Policy.

RRTP-NRT-2004 (2014). Eurokodi 8 - For Construction and Masonry Constructions (in Albanian). Tirana: Institute of Construction Technology Studies.
RS-89/2019 (2019). Rules for Construction (in Serbian). Official Gazette of the Republic of Serbia n.89 of 18 December 2019, Belgrade.

RSCCS (1958). Decreto n.41658 - Safety Regulation of Constructions Against Earthquakes (in Portuguese). Diário do Governo n.117 de 31 de Maio de 1958, Lisbon.

SAC-2012-2 (2013). Syrian Arab Code for the Design and Implementation of Reinforced Concrete Structures, Fourth Edition - Annex 2 Earthquake Design of Buildings, Second Edition (in Arabic). Damascus: Syrian Engineers Association.

SBC 305-Cr (2018). Saudi Masonry Code, Code Requirements (in Arabic). Riyadh: Saudi Building Code National Committee.

Schildkamp, M., and Araki, Y. (2019b). Cost analysis of mountain schools in Nepal: comparison of earthquake resistant features in rubble stone masonry vs. Concrete block masonry. Front. Built Environ. 5:55. doi: 10.3389/fbuil.2019. 00055

Schildkamp, M., and Araki, Y. (2019a). School buildings in rubble stone masonry with cement mortar in seismic areas: literature review of seismic codes, technical norms and practical manuals. Front. Built Environ. 5:13. doi: 10.3389/ fbuil.2019.00013

SFRY-31/81 (1981). Code of Technical Regulations for the Construction of Buildings in Seismic Regions (in Serbo-Croatian). Official Gazette of the Socialist Federal Republic of Yugoslavia n.31 of 5 June 1981, Belgrade.

SFRY-39/64 (1964). Ordinance on Temporary Technical Regulations for Construction in Seismic Regions (in Serbo-Croatian). Official Gazette of the Socialist Federal Republic of Yugoslavia n.39 of 30 September 1964, Belgrade.

SFRY-52/90 (1990). Code of Technical Regulations for the Construction of Buildings in Seismic Regions (in Serbo-Croatian). Official Gazette of the Socialist Federal Republic of Yugoslavia n.52 of 7 September 1990, Belgrade.

SI-431-1995 (2013). Design Provisions for Earthquake Resistance of Structures, Amendment no.5 (in English). Tel Aviv: The Standards Institution of Israel.

Silva, V., Yepes-Estrada, C., Dabbeek, J., Martins, L., and Brzev, S. (2018). GED4ALL-Global Exposure Database for Multi-Hazard Risk Analysis-MultiHazard Exposure Taxonomy. GEM Technical Report 2018-01. Pavia: GEM Foundation.

SN 8-57 (1958). Norms and Rules of Construction in Seismic Regions (in Russian). Moscow: State Committee of the Council of Ministers of the USSR for Construction.

SN KR 20-02:2018 (2018). Earthquake Engineering. Seismic Design Codes (in Kyrgyz and Russian). Bishkek: State Agency of Architecture.

SNiP I-A.1 (1955). Materials and Products from Natural Stone (in Russian). Moscow: State Committee of the Council of Ministers of the USSR for Construction.

SNiP I-B.8-62 (1962). Materials and Products from Natural Stone (in Russian). Moscow: State Committee of the Council of Ministers of the USSR for Construction.

SNiP II-7-81* (1989). Construction in Seismic Areas, with Amendments 1,2 (in Russian). Moscow: State Committee of the Council of Ministers of the USSR for Construction.

SNiP II-A.12-69* (1977). Construction in Seismic Areas. Design Standards, with Amendments (in Russian). Moscow: State Committee of the Council of Ministers of the USSR for Construction.

SNiP KR 20-02:2009 (2017). Earthquake Engineering. Seismic Design Codes (in Russian). Bishkek: State Agency for Architecture and Construction under the Government of the Kyrgyz Republic.

SNT 2.01.08-99 (2000). Construction in Seismic Regions. Section 1: Residential, Public, Industrial Buildings and Structures (in Turkmen and Russian). Ashgabat: National Committee for Architectural and Construction Control under the Cabinet of Ministers of Turkmenistan.

SP 14.13330.2018 (2018). Construction in Seismic Areas. Updated Edition of SNiP II-7-81* (in Russian). Moscow: Ministry of Construction Industry.

SP 52.13330.2016 (2017). Natural and Artificial Lighting (in Russian). Moscow: Ministry of Construction Industry.

Standard 2800 (1987). Iranian Code of Practice for Seismic Resistant Design of Buildings, 1st Edn. (in English). Tehran: Building and Housing Research Center.

Standard 2800 (2015). Iranian Code of Practice for Seismic Resistant Design of Buildings, 4th Edn. (in Farsi). Tehran: Building and Housing Research Center.

State Committee for Construction and Architecture (1957). Regulations for Design of Buildings and Engineering Structures in the Seismic Regions of the People's Republic of Bulgaria (in Bulgarian). State Journal n. 65 of 13 August, 1957, Sofia. 
TBDY (2018). Turkish Seismic Building Regulations. Resmî Gazete n.30364 of 18/03/2018 (in Turkish). Ankara: Disaster and Emergency Management Presidency.

Thinley, K., Hao, H., and Tashi, C. (2017). Seismic Performance of Reinforced Concrete Buildings in Thimpu, Bhutan. Int. J. Struct. Stab. Dyn. 17:1750074. doi: $10.1142 / S 0219455417500742$

TJ 11-78 (1979). Code for the Seismic Design of Civil and Industrial Buildings (in Chinese). Beijing: State Construction Committee.

TS EN 771-6+A1 (2015). Specification for Masonry Units - Part 6: Natural Stone Masonry Units (in English). Ankara: Turkish Standard Institution.

UBC-1997 (1997). Uniform Building Code, Volume 2, Structural Engineering Design Provisions. Whittier: International Conference of Building Officials.

UNECE (2011). Country Profiles on the Housing Sector, Tajikistan. Geneve: United Nations Economic Commission for Europe.

UNECE (2017). Country Profiles on Housing and Land Management; Republic of Armenia, report ECE/HBP/186. Geneva: United Nations Economic Commission for Europe.
World Bank (2020). Rural Population (\% of Total Population) - Uzbekistan, Tajikistan, Turkmenistan, Kyrgyz Republic, Kazakhstan. Washington, DC: The World Bank Group.

ZMMYT-44 (1944). Temporary Construction Guidelines for Earthquake Regions (in Turkish). Ankara: Yeni Cezaevi Printing House.

Conflict of Interest: The authors declare that the research was conducted in the absence of any commercial or financial relationships that could be construed as a potential conflict of interest.

Copyright () 2020 Schildkamp, Silvestri and Araki. This is an open-access article distributed under the terms of the Creative Commons Attribution License (CC BY). The use, distribution or reproduction in other forums is permitted, provided the original author(s) and the copyright owner(s) are credited and that the original publication in this journal is cited, in accordance with accepted academic practice. No use, distribution or reproduction is permitted which does not comply with these terms. 